\title{
Difference between Burley Tobacco and Flue-Cured Tobacco in Nitrate Accumulation and Chemical Regulation of Nitrate and TSNA Contents
}

\author{
Yafei Li, ${ }^{1}$ Hongzhi Shi, ${ }^{1}$ Huijuan Yang, ${ }^{1}$ Jun Zhou, ${ }^{2}$ Jing Wang, \\ Ruoshi Bai, ${ }^{2}$ and Dongya $\mathrm{Xu}^{1}$ \\ ${ }^{1}$ Henan Agricultural University, National Tobacco Cultivation \& Physiology \& Biochemistry Research Center, \\ Zhengzhou 450002, China \\ ${ }^{2}$ Beijing Cigarette Factory of Shanghai Tobacco Group, Beijing 100024, China
}

Correspondence should be addressed to Hongzhi Shi; zhihongshi@163.com

Received 11 July 2017; Accepted 6 November 2017; Published 6 December 2017

Academic Editor: Davide Vione

Copyright (C) 2017 Yafei Li et al. This is an open access article distributed under the Creative Commons Attribution License, which permits unrestricted use, distribution, and reproduction in any medium, provided the original work is properly cited.

\begin{abstract}
Tobacco-specific nitrosamines (TSNAs) are harmful carcinogens, with nitrate as a precursor of their formation. Nitrate content is considerably higher in burley tobacco than in flue-cured tobacco, but little has been reported on the differences between types of nitrate accumulation during development. We explored nitrate accumulation prior to harvest and examined the effects of regulatory substances aimed at decreasing nitrate and TSNA accumulation. In growth experiments, nitrate accumulation in burley and flue-cured tobacco initially increased but then declined with the highest nitrate content observed during a fast-growth period. When treating tobacco crops with molybdenum (Mo) during fast growth, nitrate reductase activity in burley tobacco increased significantly, but the $\mathrm{NO}_{3}-\mathrm{N}$ content decreased. These treatments also yielded significant reductions in $\mathrm{NO}_{3}-\mathrm{N}$ and TSNA contents Therefore, we suggest that treatment with Mo during the fast-growth period and a Mo-Gfo (Mo-glufosinate) combination at the maturity stage is an effective strategy for decreasing nitrate and TSNAs during cultivation.
\end{abstract}

\section{Introduction}

Eight types of tobacco-specific nitrosamines (TSNAs) are present in tobacco with the majority known to cause malignant tumors in mice, rats, and hamsters [1, 2]. $N^{\prime}$-Nitrosonornicotine (NNN), 4-(methylnitrosamino)-1-(3pyridyl)-l-butanone (NNK), $N^{\prime}$-nitrosoanabasine (NAB), and $N^{\prime}$-nitrosoanatabine (NAT) are key TSNAs with NNN and NNK classified as group 1 carcinogens by the International Agency for Research on Cancer [3]. The formation of TSNAs during the curing process can be affected by the concentrations of their nitrate and alkaloid precursors in tobacco [4]. High temperature and humidity in air-curing barns or high moisture in tobacco can significantly promote TSNA formation. Good ventilation in burley curing barns and improved storage conditions contribute to decreased TSNA formation [5]. We have previously found that TSNAs in cured tobacco may greatly increase with exogenous nitrate application during storage [6]. Therefore, reducing nitrate accumulation has become a research focus for decreasing TSNA formation.

Nitrate $\left(\mathrm{NO}_{3}{ }^{-}\right)$is one of the major nitrogen sources taken up by plants $[7,8]$, which can lead to accumulation in cell vacuoles if it is not reduced, reutilized, or transported into cytoplasm $[9,10]$. If consumed, nitrate is harmful to the human body. Nitrate can be reduced to nitrite, which is reoxidized to nitrate by oxyhemoglobin in the bloodstream resulting in the formation of methemoglobin and impairing the capacity of blood to deliver oxygen to body tissues [11-14]. This condition is referred to as methemoglobinemia and it is harmful to older children and adults. Nitrate is also one of the main precursors contributing to formation and accumulation of TSNAs [4]. Nitrate is present at concentrations tens to hundreds of times higher in burley tobacco than in flue-cured tobacco, with the reasons for this accumulation unclear. 
Many factors such as nitrogen management, soil fertility, tobacco types and varieties, and cultivation conditions are related to nitrate accumulation [4]. Increased nitrogen application generally gives rise to higher levels of nitrate, and low nitrogen efficiency tobacco varieties usually have higher nitrate accumulation than high-efficiency varieties under the same soil nitrogen level [15, 16]. Differences in nitrate accumulation among varieties are mainly due to their differential capacities in absorbing, reducing, and assimilating nitrate [16-19], with high assimilation regarded as a main contributor to low nitrate concentration in the lamina $[19,20]$. Enzymes such as nitrate reductase (NR) and glutamine synthetase (GS) are important in nitrogen metabolism, and their activities have significant effects on nitrate accumulation in tobacco. The molybdenum (Mo) cofactor is part of NR composition [20], and symptoms of Mo deficiency and $\mathrm{N}$ deficiency are similar in plants [21]. Mo application for seed priming and foliar spray is a method widely used to enhance crop productivity [22] and is effective in increasing the relative chlorophyll index, plant height, leaf area index, dry matter production, and crop yield [23, 24]. However, there has been little research into the application of Mo to decrease nitrate and TSNA accumulation. Glufosinate (Gfo) is a low-residue and effective herbicide in agriculture cultivation, known to inhibit glutamine synthetase activity (GSA) and lead to ammonium accumulation as well as the inhibition of photorespiration and photosynthesis in plants [25-31]. Some investigators have reported that glufosinate may inhibit the growth of bacteria [32] which may promote TSNA formation during the tobacco curing stage [4]. Various doses of Gfo herbicide produce different responses inhibiting GSA in plants, with some investigators reporting that spraying a suitable amount of Gfo could improve maturity quality in tobacco [33]. However, there is little information regarding spraying Gfo to decrease TSNAs in tobacco cultivation.

The objective of the present study was to explore characteristics of nitrate accumulation in both burley and fluecured tobacco and compare the differences between types in nitrate reductase activity (NRA) and NRA/nitrogen application (NA) to develop strategies for their regulation during cultivation. A field experiment using chemical regulation was conducted to decrease nitrate and TSNA concentrations in flue-cured tobacco, and the effects of spraying regulated substances on burley varieties TN86 and TN90 were analyzed to determine an effective method for reducing nitrate and TSNA concentrations in burley tobacco. The effects of spraying Mo during the fast-growth period and at the maturity stage and of spraying Mo and Gfo together at maturity on NRA, GSA, ammonia volatilization rate (AVR), soluble protein content (SPRO), TSNAs, and TSNA precursors were determined.

\section{Methods}

2.1. Experiment 1: Growth Experiments of Burley and FlueCured Tobacco. Field and pot experiments were conducted in 2015 in Henan, China $\left(33^{\circ} 15^{\prime} 52.14^{\prime \prime} \mathrm{N}, 112^{\circ} 55^{\prime} 28.51^{\prime \prime} \mathrm{E}\right)$, using two tobacco types to explore nitrate accumulation in tobacco. Two burley tobacco genotypes, TN86 and KT204, and two cultivars of flue-cured tobacco, honghuadajinyuan (HD) and yunyan 87 (Y87), were used. Mean temperature and precipitation in this region were $24.1^{\circ} \mathrm{C}$ and $510 \mathrm{~mm}$, respectively, during tobacco cultivation season (from May to September each year).

2.1.1. Field Experiments. The soil in the field was mainly yellow loamy soil. Soil properties were tested at a depth of $0-30 \mathrm{~cm}$ before transplanting and consisted of an organic matter content of $13.55 \mathrm{~g} \mathrm{~kg}^{-1}$, available $\mathrm{N}$ of $55.01 \mathrm{mg} \mathrm{kg}^{-1}$, available $\mathrm{K}$ of $120.63 \mathrm{mg} \mathrm{kg}^{-1}$, and available $\mathrm{P}$ of $18.21 \mathrm{mg} \mathrm{kg}^{-1}$, and a $\mathrm{pH}$ of 7.13. Nitrogen application was $45 \mathrm{~kg} \mathrm{ha}^{-2}$ and $180 \mathrm{~kg} \mathrm{ha}^{-2}$ for flue-cured tobacco and burley tobacco, respectively. Plants were placed at a density of one plant per $0.605 \mathrm{~m}^{2}$ (column and line spacing per plant: $0.55 \times 1.10 \mathrm{~m}$, resp.) in field experiments. Tobacco seedlings were transplanted to the field on May 1, 2015. Burley tobacco was cut once, on July 17, 2015, and flue-cured tobacco was picked 3-5 times beginning on July 12 at 7-9-day intervals. Experimental treatments consisted of a randomized block design with three replicates. Leaf biomass was collected at 30, 45, 60, and 75 days after transplantation (DAT) in field-grown plants, with the final samples picked just prior to harvest. Fresh leaves were fixed for $20 \mathrm{~min}$ at $105^{\circ} \mathrm{C}$ and then dried for $48 \mathrm{~h}$ at $60^{\circ} \mathrm{C}$. NRA and $\mathrm{NO}_{3}-\mathrm{N}$ contents in leaf were determined at $30,45,60$, and 75 DAT in field.

2.1.2. Pot Experiments. For the pot experiments, the soil was mainly yellow loamy soil. Soil was tested at a depth of $0-30 \mathrm{~cm}$ before transplanting and was similar to that of the field experiments with an organic matter content of $13.55 \mathrm{~g} \mathrm{~kg}^{-1}$, available $\mathrm{N}$ of $55.10 \mathrm{mg} \mathrm{kg}^{-1}$, available $\mathrm{K}$ of $120.76 \mathrm{mg} \mathrm{kg}^{-1}$, available $\mathrm{P}$ of $18.20 \mathrm{mg} \mathrm{kg}^{-1}$, and a $\mathrm{pH}$ of 7.13. Nitrogen application was $45 \mathrm{~kg} \mathrm{ha}^{-2}$ and $180 \mathrm{~kg} \mathrm{ha}^{-2}$ for flue-cured tobacco and burley tobacco, respectively. Plants were placed at a density of one plant per $0.605 \mathrm{~m}^{2}$ (column and line spacing per plant: $0.55 \times 1.10 \mathrm{~m}$, resp.) and transplanted to pots with a $50 \mathrm{~cm}$ outer diameter, $42.5 \mathrm{~cm}$ inner diameter, and $33 \mathrm{~cm}$ height and were buried to a depth of $20-25 \mathrm{~cm}$ on May 15, 2015. Leaf biomass was collected after transplantation at 15, 30, 45, and 60 DAT, with the final samples picked just before harvest. $\mathrm{NRA}$ and $\mathrm{NO}_{3}-\mathrm{N}$ contents in the leaves were determined at $15,30,45$, and 60 DAT.

\subsection{Experiment 2: Nitrate Regulation of Flue-Cured Tobacco} Using Chemical Treatments. Nitrate regulation experiments were conducted in 2014 (Yunnan, China, $25^{\circ} 21^{\prime} 17.37^{\prime \prime} \mathrm{N}$, $100^{\circ} 28^{\prime} 6.75^{\prime \prime} \mathrm{E}$ ) and 2015 (Henan, China, $33^{\circ} 15^{\prime} 52.14^{\prime \prime} \mathrm{N}$, $\left.112^{\circ} 55^{\prime} 28.51^{\prime \prime} \mathrm{E}\right)$ using flue-cured tobacco (HD).

2.2.1. Soil Property Experiments in Yunnan in 2014. The soil in which the plants were grown was mainly paddy soil with a mean temperature and precipitation of $18.5^{\circ} \mathrm{C}$ and $625 \mathrm{~mm}$, respectively, during tobacco cultivation season from May to September each year. Soil properties were tested at a depth of $0-20 \mathrm{~cm}$ prior to transplantation and had an organic matter content of $22.4 \mathrm{~g} \mathrm{~kg}^{-1}$, available $\mathrm{N}$ of $120.01 \mathrm{mg} \mathrm{kg}^{-1}$, available $\mathrm{K}$ of $154.63 \mathrm{mg} \mathrm{kg}^{-1}$, P of $28.4 \mathrm{mg} \mathrm{kg}^{-1}$, and $\mathrm{pH}$ of 6.48 . 
2.2.2. Soil Property Experiments in Henan in 2015. Field soil was mainly yellow loamy soil. Annual mean temperature and precipitation in this region were $24.1^{\circ} \mathrm{C}$ and $510 \mathrm{~mm}$, respectively, during tobacco cultivation season from May to September each year. Soil properties were tested at a depth of $0-30 \mathrm{~cm}$ before transplanting and had an organic matter content of $13.55 \mathrm{~g} \mathrm{~kg}^{-1}$, available $\mathrm{N}$ of $55.01 \mathrm{mg} \mathrm{kg}^{-1}$, available $\mathrm{K}$ of $120.63 \mathrm{mg} \mathrm{kg}^{-1}$, and available $\mathrm{P}$ of $18.21 \mathrm{mg} \mathrm{kg}^{-1}$, and $\mathrm{pH}$ of 7.13 . Nitrogen applications were $75 \mathrm{~kg} \mathrm{ha}^{-2}$ and $45 \mathrm{~kg} \mathrm{ha}^{-2}$ in 2014 and 2015, respectively. Tobacco seedlings were transplanted on May 7, 2014, and May 1, 2015. Spraying during fastgrowth periods or at the stage of maturity was carried out on June 17 and July 15, 2014, and June 11 and July 10, 2015, respectively. TSNAs, $\mathrm{NO}_{3}-\mathrm{N}, \mathrm{NO}_{2}-\mathrm{N}$, and alkaloids in the tobacco were determined after curing. Field management was carried out according to conventional practice.

The following treatments were applied:

(1) A control treatment, wherein water only was sprayed during the fast-growth and maturity stages (CK)

(2) Sodium molybdate sprayed during the fast-growth period (FG-Mo)

(3) Sodium molybdate sprayed during the fast-growth period and Gfo sprayed at the stage of maturity (MGfo)

(4) Sodium molybdate sprayed during the fast-growth period and sodium molybdate combined with Gfo sprayed at the maturity stage (M-Mo + Gfo).

Sodium molybdate (Mo) and Gfo doses were determined in preliminary tests, and $10 \mathrm{mg} \mathrm{L}^{-1} \mathrm{Gfo}(\mathrm{v} / \mathrm{v})$ and $0.5 \%(\mathrm{~m} / \mathrm{m})$ Mo were screened out to spray in field experiments. The dose of Gfo sprayed on tobacco $\left(0.01 \mathrm{~kg} \mathrm{hm}^{-2}\right)$ was much lower than its use as a herbicide during agriculture cultivation $\left(0.40 \mathrm{~kg} \mathrm{hm}^{-2}\right.$ used to control annual weeds and $1-2 \mathrm{~kg} \mathrm{hm}^{-2}$ used to control perennial weeds) [34]. Residual Gfo in leaves was low, with remaining Gfo decreasing by $15 \%$ three days after spraying [35].

\subsection{Experiment 3: Nitrate Regulation of Burley Tobacco Using} Chemical Treatments. Nitrate regulation experiments on burley tobacco (TN86 and KT204 varieties) were conducted in 2015 in Henan, China $\left(33^{\circ} 15^{\prime} 52.14^{\prime \prime} \mathrm{N}, 112^{\circ} 55^{\prime} 28.51^{\prime \prime} \mathrm{E}\right)$. Soil conditions, treatments, and management were as described in experiment 2. NRA and $\mathrm{NO}_{3}-\mathrm{N}$ content were determined five days after spraying during the fast-growth period. NRA, GSA, $\mathrm{NO}_{3}-\mathrm{N}$, and SPRO were determined at the seventh day after spraying, and ammonia volatilization was measured for one full $24 \mathrm{~h}$ period from 08:00 to 08:00 on the seventh day after spraying at the stage of maturity. AVR was calculated as the ratio of the amount of ammonia volatilization over time. TSNAs, $\mathrm{NO}_{3}-\mathrm{N}, \mathrm{NO}_{2}-\mathrm{N}$, and alkaloids in the tobacco were determined after curing.

The length of the various stages of tobacco development is as follows [36, 37]: (1) recovery (adaptation), 30-35 days; (2) budding (knee-high, fast growth, and elongation), 20-30 days; (3) maturity (flowering and topping, beginning of harvest, and seed formation), 45-60 days.
2.4. Chemical Characterization of Soil. Soil $\mathrm{pH}$ was determined in $1: 2.5(\mathrm{v} / \mathrm{v})$ soil/water suspension, organic matter content was determined using the potassium bichromate titrimetric method, available nitrogen was measured by using the alkaline hydrolysis diffusion method, available potassium was measured using the neutral ammonium acetate extraction method, and available phosphorus was determined using alkaline sodium bicarbonate as the extractant in a $20: 1$ ratio [38].

2.5. Measurement of NRA, GSA, SPRO, and AVR. Tobacco leaves were sampled at 10:00-11:00 a.m. on sunny days. Samples were frozen and fresh leaves without veins were cut into $2 \times 5 \mathrm{~mm}$ pieces before measurement. NRA was measured based on the method described by Li [39]. GSA was determined as per O'Neal and Joy [40]. SPRO was assayed according to Li [39]. AVR was determined by the method using airtight equipment [41, 42].

2.6. Measurement of Total Nitrogen (TN) Content, $\mathrm{NO}_{3^{-}}$ $\mathrm{N}, \mathrm{NO}_{2}-\mathrm{N}, \mathrm{TSNAs}$, and Alkaloids. Tobacco samples were lyophilized, ground, and sieved through a $0.25 \mathrm{~mm}$ screen prior to measurement. TN was determined using methods modified from the Chinese Tobacco Industry standard (YC/T 161,159-2002). Samples of $0.1 \mathrm{~g}$ powder mixture containing $0.1 \mathrm{~g} \mathrm{CuSO}_{4}$ and $1 \mathrm{~g} \mathrm{~K}_{2} \mathrm{SO}_{4}$ were mixed with $5 \mathrm{~mL}$ of concentrated $\mathrm{H}_{2} \mathrm{SO}_{4}(98.3 \% \mathrm{~m} / \mathrm{m})$ in a $50 \mathrm{~mL}$ digestion tube and held for $1-2 \mathrm{~h}$ at room temperature. Samples were then warmed to $150^{\circ} \mathrm{C}$ for $30 \mathrm{~min}, 250^{\circ} \mathrm{C}$ for $30 \mathrm{~min}$, and $370^{\circ} \mathrm{C}$ for $2 \mathrm{~h}$ in a furnace (DS53-380, CIF, USA). After cooling, approximately $10 \mathrm{~mL}$ deionized water was added, and samples were shaken thoroughly. Sample mixtures were cooled for 1-2 h, and water was added to maintain the overall volume of the samples. The mixtures were then cooled for $1 \mathrm{~h}$ and filtered. $\mathrm{TN}$ in the supernatant was determined using flow-injectionanalysis (AA3, Bran + Luebbe, Germany).

$\mathrm{NO}_{3}-\mathrm{N}$ and $\mathrm{NO}_{2}-\mathrm{N}$ were quantified according to Crutchfield and Grove [43]. The individual alkaloids were analyzed using a gas chromatograph as described by Jack and Bush [43]. Methyl tert-butyl ether was applied as the extraction solvent with $\mathrm{N}$-hexadecane according to internal standards [44]. NNN, NNK, NAT, and NAB contents were determined according to SPE-LC-MS/MS methods [45-47]. The total TSNA concentration was calculated by summing the NNN, NNK, NAT, and NAB [6].

2.7. Statistical Analyses. Comparisons were made using analyses of variance (ANOVAs) and least significant differences for NRA, GSA, AVR, $\mathrm{NO}_{X}$, alkaloids, and TSNAs with $p<$ 0.05 considered significant based on three replicates. Data were analyzed in Statistical Package for the Social Sciences (SPSS 20.0), and figures were created using Origin 9.0. Pearson correlations were used to analyze the relationships between TSNAs and their precursors.

\section{Results and Discussion}

3.1. Features of $\mathrm{NO}_{3}-\mathrm{N}$ Content and NRA in Flue-Cured Tobacco and Burley Tobacco. In field and pot experiments, nitrate content in both burley tobacco and flue-cured tobacco 
TABLE 1: ANOVA results of the effects of chemical regulation, year, and tobacco variety and their interactions on LDM and DM before harvest.

\begin{tabular}{|c|c|c|c|c|c|c|c|}
\hline Year & Treatment & LDM (g/plant) & $\mathrm{DM}$ (g/plant) & Variety & Treatment & LDM (g/plant) & $\mathrm{DM}$ (g/plant) \\
\hline \multirow{4}{*}{2014} & CK & $130.70 \pm 7.33^{b}$ & $240.70 \pm 7.91^{\mathrm{a}}$ & \multirow{4}{*}{ KT204 } & CK & $124.13 \pm 3.26^{\mathrm{ab}}$ & $244.13 \pm 4.42^{\mathrm{a}}$ \\
\hline & FG-Mo & $149.35 \pm 3.49^{\mathrm{a}}$ & $260.35 \pm 3.78^{\mathrm{a}}$ & & FG-Mo & $134.05 \pm 3.52^{\mathrm{a}}$ & $256.05 \pm 4.68^{\mathrm{a}}$ \\
\hline & M-Gfo & $114.33 \pm 2.75^{c}$ & $224.33 \pm 2.89^{b}$ & & M-Gfo & $118.49 \pm 2.26^{\mathrm{b}}$ & $237.49 \pm 4.41^{\mathrm{a}}$ \\
\hline & $\mathrm{M}-\mathrm{Mo}+\mathrm{Gfo}$ & $137.85 \pm 2.78^{\mathrm{ab}}$ & $247.85 \pm 3.35^{\mathrm{a}}$ & & $\mathrm{M}-\mathrm{Mo}+\mathrm{Gfo}$ & $128.17 \pm 3.15^{\mathrm{ab}}$ & $248.17 \pm 4.30^{\mathrm{a}}$ \\
\hline \multirow{4}{*}{2015} & CK & $142.70 \pm 5.84^{\mathrm{a}}$ & $255.70 \pm 7.55^{\mathrm{a}}$ & \multirow{4}{*}{ TN86 } & $\mathrm{CK}$ & $113.41 \pm 4.54^{\mathrm{ab}}$ & $215.41 \pm 5.69^{\mathrm{ab}}$ \\
\hline & FG-Mo & $155.27 \pm 4.99^{\mathrm{a}}$ & $268.60 \pm 7.01^{\mathrm{a}}$ & & FG-Mo & $125.34 \pm 2.92^{\mathrm{a}}$ & $233.01 \pm 4.37^{\mathrm{a}}$ \\
\hline & M-Gfo & $141.02 \pm 4.30^{\mathrm{a}}$ & $254.02 \pm 6.03^{\mathrm{a}}$ & & M-Gfo & $104.13 \pm 3.38^{\mathrm{b}}$ & $204.13 \pm 4.53^{\mathrm{b}}$ \\
\hline & $\mathrm{M}-\mathrm{Mo}+\mathrm{Gfo}$ & $151.52 \pm 7.20^{\mathrm{a}}$ & $264.52 \pm 8.93^{\mathrm{a}}$ & & $\mathrm{M}-\mathrm{Mo}+\mathrm{Gfo}$ & $116.65 \pm 3.28^{\mathrm{ab}}$ & $220.65 \pm 5.58^{\mathrm{ab}}$ \\
\hline & Year $(\mathrm{Y})$ & $2.02^{* *}$ & $0.65^{* *}$ & & ety $(V)$ & $0.90^{*}$ & $1.94^{* *}$ \\
\hline & Treatment (T) & $4.71^{* *}$ & $3.44^{*}$ & & ment (T) & $5.28^{* *}$ & 1.99 \\
\hline Year & )$\times$ treatment $(\mathrm{T})$ & $6.71^{* *}$ & $5.13^{* *}$ & Variety & $x$ treatment $(\mathrm{T})$ & $7.88^{* *}$ & $14.38^{* *}$ \\
\hline
\end{tabular}

Different letters within the same column indicate significant differences among treatments at $p<0.05$. Symbols $* *$ and $*$ indicate significant difference at 0.01 or 0.05 , respectively.

increased over the period of development and presented a trend of "rise-fall" prior to harvest (Figure 1). Nitrate content was at its highest during the fast-growth period. Nitrate is difficult to recycle once stored in cells [48]. Hence, avoiding nitrate accumulation during the fast-growth stage may be effective in reducing nitrate accumulation in cured tobacco.

In general, the amount of nitrogen fertilizers used on burley tobacco was almost 3-5 times higher than that used on flue-cured tobacco, but the yield was not significantly different between them [49]. NRA and $\mathrm{NO}_{3}-\mathrm{N}$ contents between burley tobacco and flue-cured tobacco were significantly different with NRA/NA in flue-cured tobacco significantly higher than in burley tobacco. During tobacco development, the $\mathrm{NO}_{3}-\mathrm{N}$ content in burley tobacco was higher than that in flue-cured tobacco in both field and pot experiments. NRA was readily affected by nitrogen application with nitrogen application on burley tobacco 4 -fold greater than that in fluecured tobacco production. NRA/NA in flue-cured tobacco was higher than in burley tobacco in both field and pot experiments. In addition, weak nitrogen assimilation of burley tobacco may be an important cause of nitrate accumulation [50].

\subsection{Effects of Chemical Regulation on Leaf Biological Yield} (LDM) and Above-Ground Dry Matter Weight (DM). LDM and DM were used to evaluate whether plants were growing well and to predict yield in tobacco cultivation [36]. It has been reported that $\mathrm{DM}$, yield, and product quality all decrease under a Mo-deficient condition [51]. In this work, LDM and DM increased with Mo being sprayed during the fast-growth period, which has been shown to dilute nitrate concentration [50]. The main effects of chemical treatment and year were significantly observed for LDM and DM over the two years of observation $(p<0.05)$ (Table 1). Variation between tobacco varieties also significantly affected LDM and DM. LDM and DM in tobacco increased under Mo treatment during the fastgrowth period. Meanwhile, LDM and DM showed a decrease with spraying of Gfo at the maturity stage.
3.3. Effects of Chemical Regulation on NRA, GSA, AVR, SPRO, and $\mathrm{NO}_{3}-\mathrm{N}$ Content. NRA and $\mathrm{NO}_{3}-\mathrm{N}$ content in both TN86 and KT204 exhibited increasing trends (Figure 2), which were closely related to the maximum uptake of nutrients during the rapid growth stage [36]. Additionally, enhancing nitrogen assimilation ability and decreasing nitrate storage were key in reducing nitrate accumulation in tobacco during this period. Under the Mo treatment during the fast-growth period, NRA in TN86 and KT204 increased by $1.57-11.81 \%$ and $1.72-10.58 \%$, respectively, but $\mathrm{NO}_{3}-\mathrm{N}$ content in $\mathrm{TN} 86$ and KT204 decreased correspondingly by $10.16-58.08 \%$ and $10.04-48.87 \%$, respectively $(p<0.01)$.

Composition of tobacco at the stage of maturity is significantly indicative of the components of cured tobacco, and improving chemical composition during this stage is useful in enhancing tobacco quality [52]. NR and GS are key enzymes in the process of nitrogen reduction and assimilation in plants, and GS plays an important role in the first step of $\mathrm{NH}_{4}{ }^{+}$assimilation [53]. NRA, AVR, GSA, and SPRO in burley tobacco were significantly affected by spraying Gfo at the maturity stage (Figures $3(\mathrm{a})-3(\mathrm{~h})$ ). Gfo application can inhibit GSA and cause ammonia emissions of almost $10 \%$ of canopy nitrogen content [26]. Compared with CK, the GSA and SPRO of Gfo-sprayed tobacco significantly decreased, and AVR significantly increased. Hence, spraying Mo and Gfo at maturity was effective in decreasing nitrate accumulation and promoting nitrogen loss in tobacco (Figure 8).

3.4. Effects of Chemical Regulation on TSNA Precursors. $\mathrm{NO}_{3}-\mathrm{N}, \mathrm{NO}_{2}-\mathrm{N}$, and alkaloids are precursors of TSNAs, and decreasing precursors is effective in reducing TSNA formation in tobacco. Sufficient $\mathrm{NO}_{3}-\mathrm{N}$ content can greatly promote TSNA formation during tobacco storage, and reducing $\mathrm{NO}_{3}-\mathrm{N}$ accumulation is key in decreasing TSNA formation [54]. As shown above, treatment with Mo and Gfo significantly decreased $\mathrm{TN}, \mathrm{NO}_{3}-\mathrm{N}, \mathrm{NO}_{2}-\mathrm{N}$, and $\mathrm{NO}_{3}$ N/TN but did not affect alkaloid levels in burley tobacco (Figures $4(\mathrm{a})-4(\mathrm{j})$ ). Spraying Mo during periods of fast 


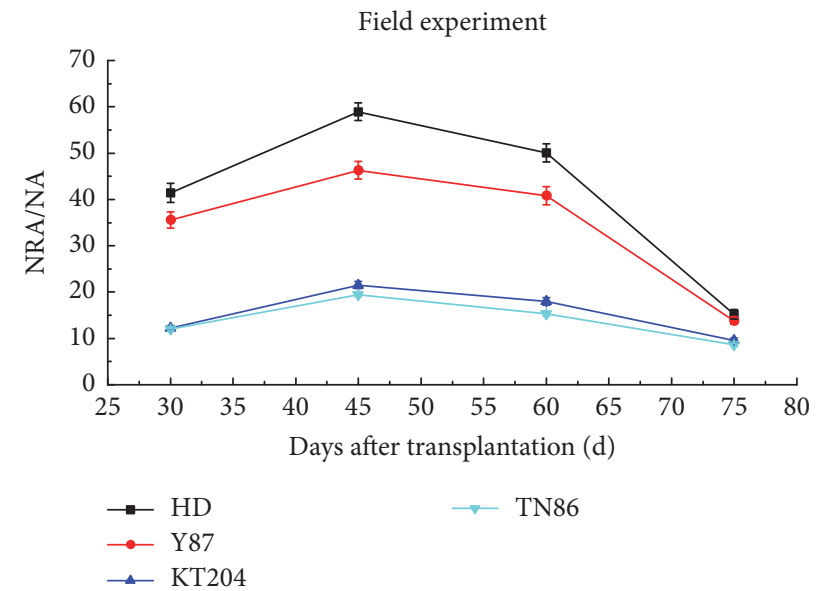

(a)

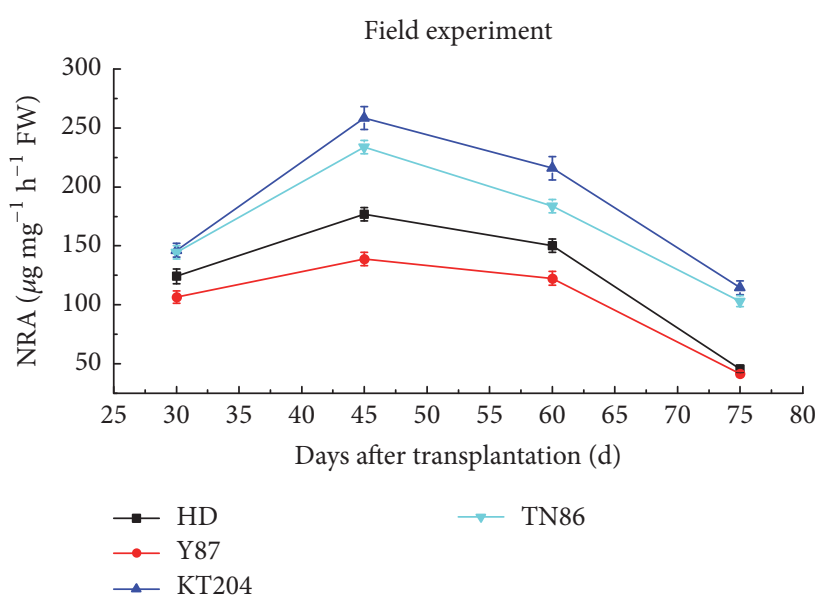

(c)

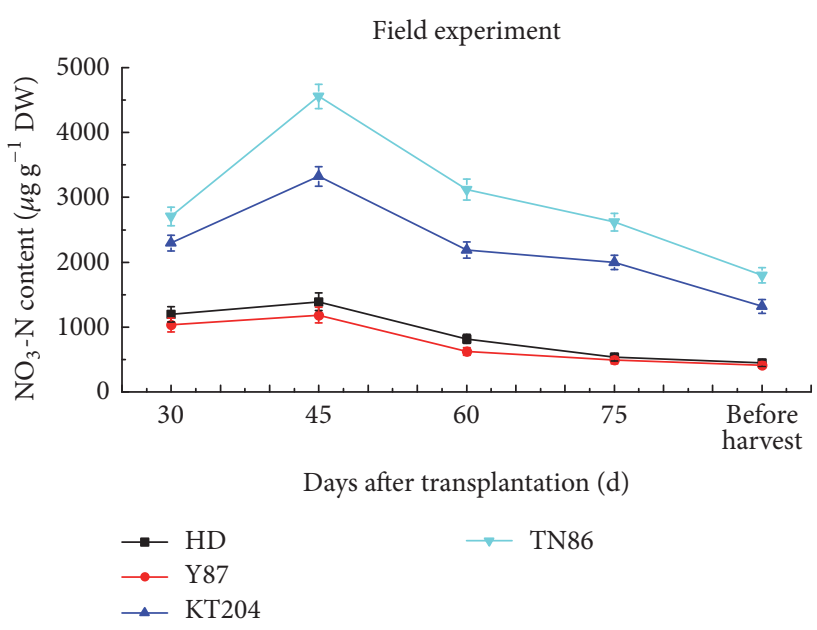

(e)

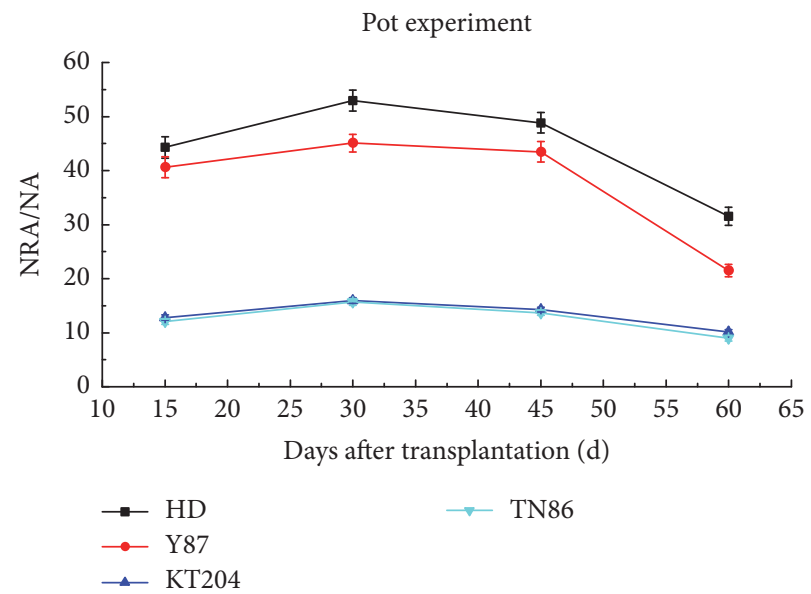

(b)

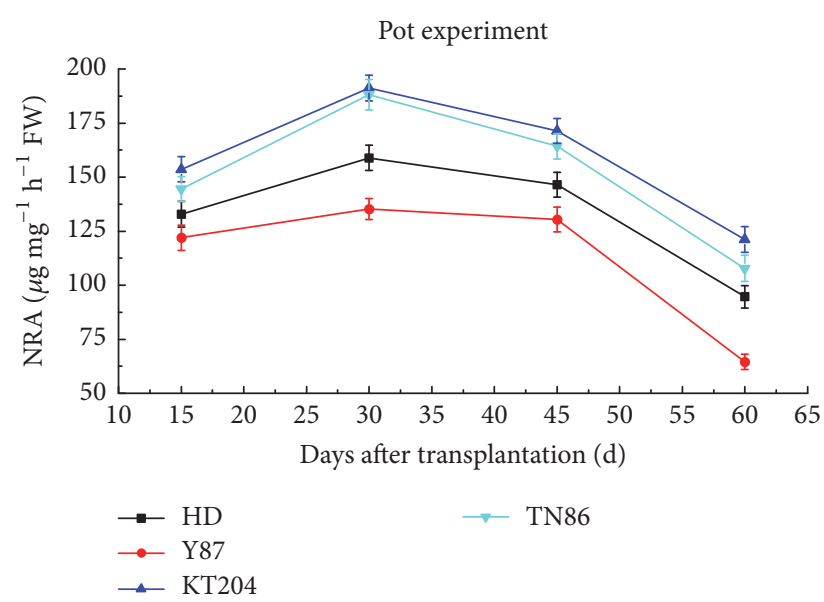

(d)

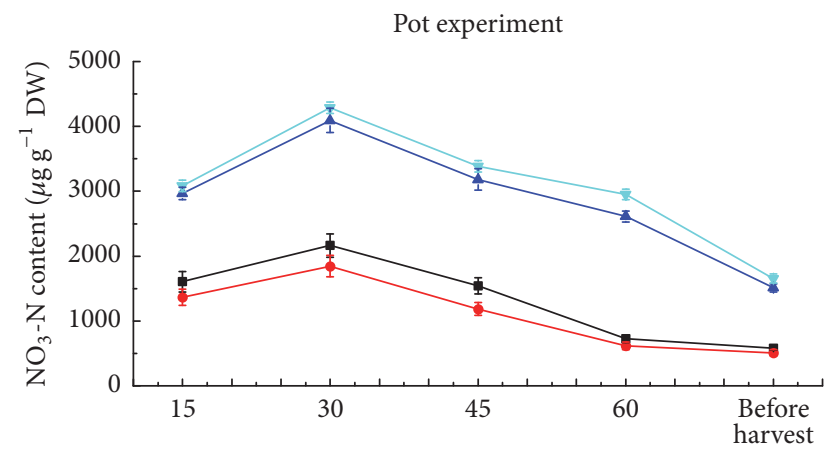

Days after transplantation (d)

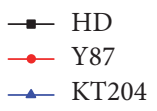

$\rightarrow$ Y87

$\_$KT204

FIGURE 1: Difference between burley tobacco and flue-cured tobacco in NRA, NRA/NA, and $\mathrm{NO}_{3}-\mathrm{N}$ content of leaves. Burley tobacco varieties were KT204 and TN86, and flue-cured tobacco varieties were HD and Y87. NA: nitrogen application (HD and Y87: 45 kg ha ${ }^{-2}$, KT204 and TN86: $\left.180 \mathrm{~kg} \mathrm{ha}^{-2}\right)$. NRA: nitrate reductase activity. Error bars indicate standard error of the means $(n=3)$. 


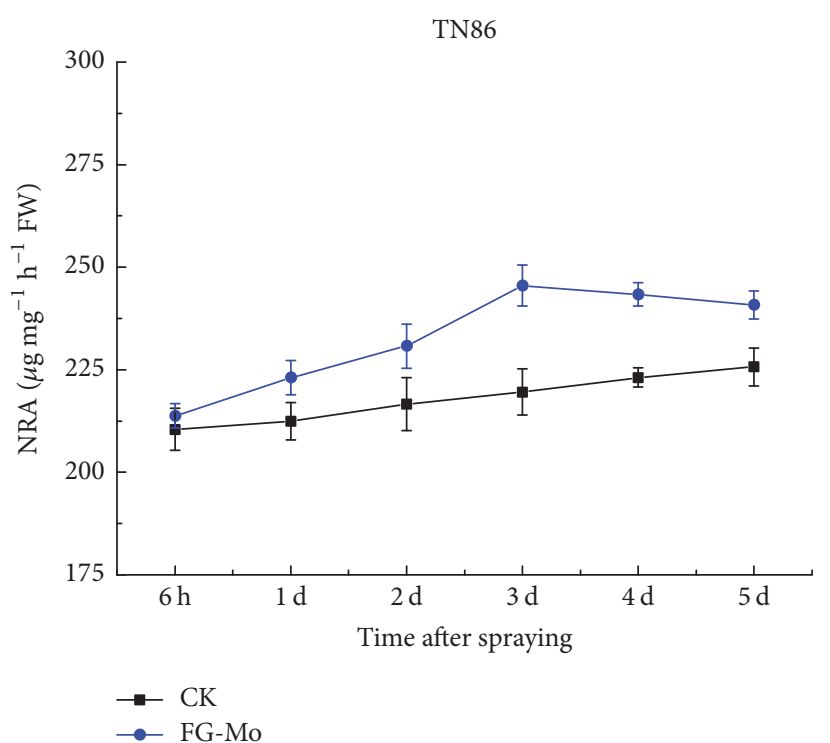

(a)

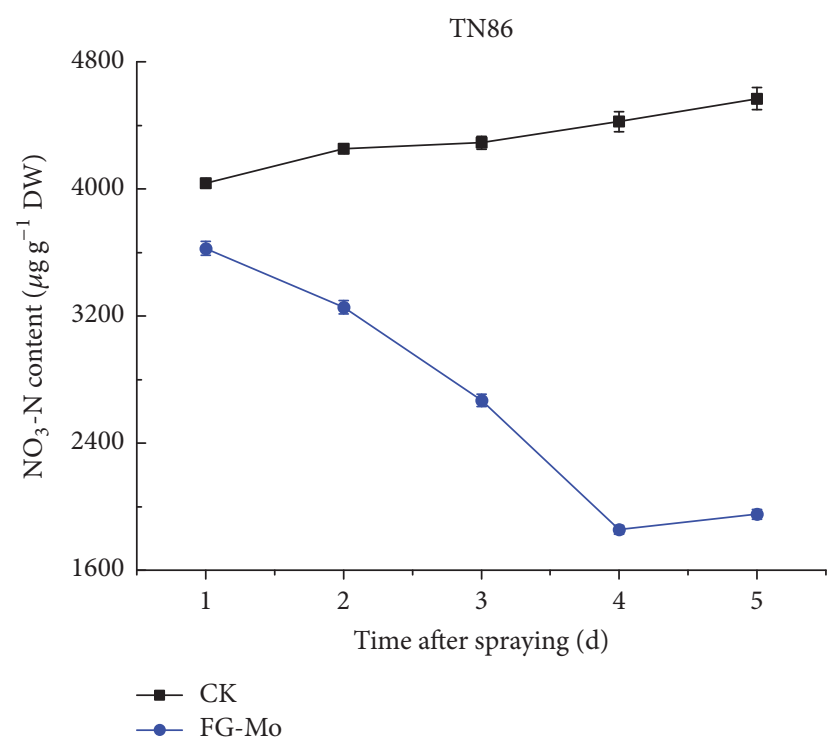

(c)

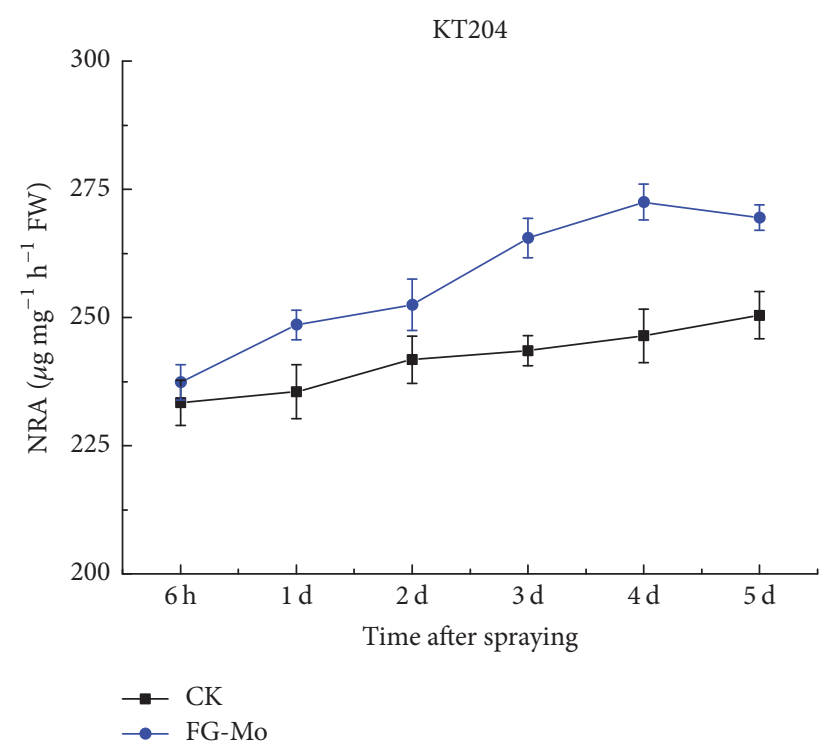

(b)

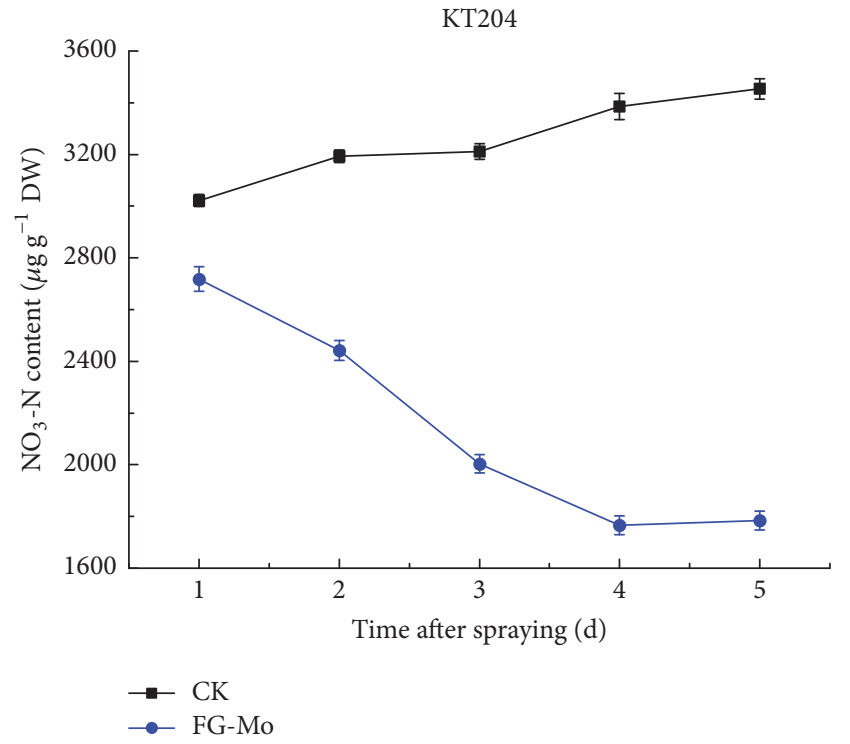

(d)

Figure 2: Changes in the NRA and $\mathrm{NO}_{3}-\mathrm{N}$ content of burley tobacco under Mo treatment during fast-growth period. NRA: nitrate reductase activity. NRA in tobacco was determined at $6 \mathrm{~h}$ and on days $1-5$ after spraying. Error bars indicate standard error of means $(n=3)$.

growth led to significantly lower $\mathrm{NO}_{3}-\mathrm{N}$ content in KT204 and TN86. Spraying Mo during the fast-growth period and simultaneously spraying Mo and Gfo at the stage of maturity led to a significant decrease in $\mathrm{NO}_{3}-\mathrm{N}$ and $\mathrm{NO}_{2}-\mathrm{N}$ content in KT204 and TN86.

3.5. Effects of Chemical Regulation on TSNA Contents. Auxin, naphthylacetic acid, salicylic acid, and malonic acid have been previously applied to decrease TSNA formation, but these may affect tobacco development and growth, yield, or quality $[55,56]$. In this study, we aimed to characterize a chemical regulation strategy for decreasing TSNA precursors so as to diminish TSNA formation in tobacco. Yearly differences in $\mathrm{NO}_{3}-\mathrm{N}, \mathrm{NO}_{2}-\mathrm{N}$, and TSNA contents in flue-cured tobacco were significant, but TN and alkaloid levels were not (Table 2). Regulatory treatments significantly affected $\mathrm{TN}, \mathrm{NO}_{3}-\mathrm{N}$, alkaloid level, and TSNA concentrations in fluecured tobacco. Varieties of burley tobacco were different in TN, $\mathrm{NO}_{3}-\mathrm{N}, \mathrm{NO}_{2}-\mathrm{N}$, alkaloid level, and TSNA concentrations, and chemical regulation treatments significantly affected $\mathrm{TN}, \mathrm{NO}_{3}-\mathrm{N}$, and TSNA concentrations.

As can be seen in Figure 5, spraying Mo during the fastgrowth period and spraying Gfo at the stage of maturity decreased TSNA concentrations in flue-cured tobacco, but 


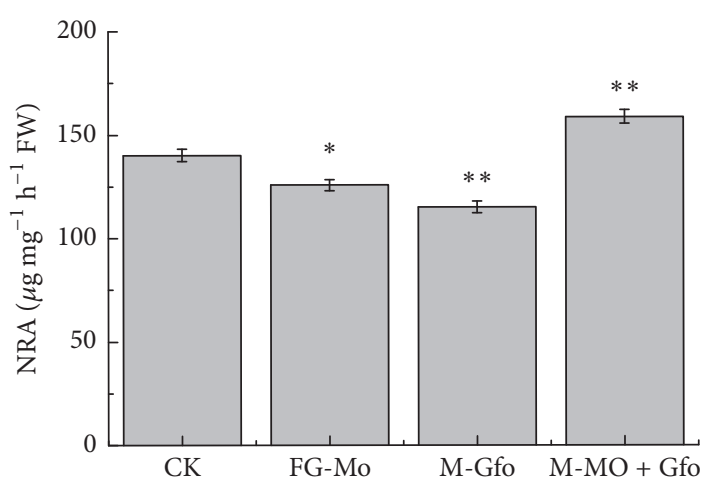

(a)

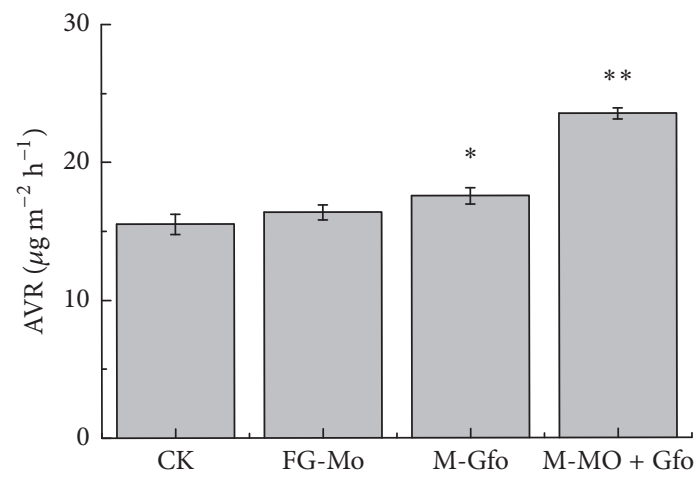

(c)

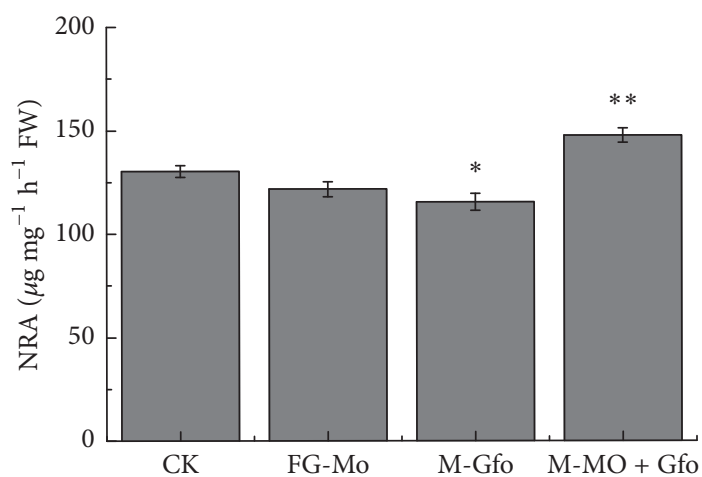

(e)

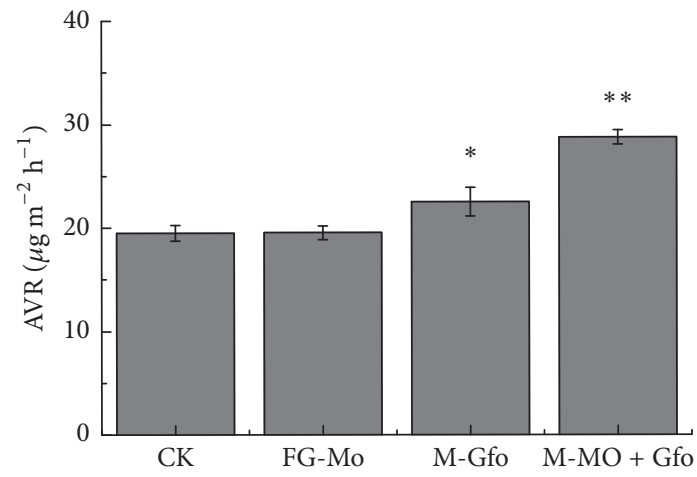

(g)

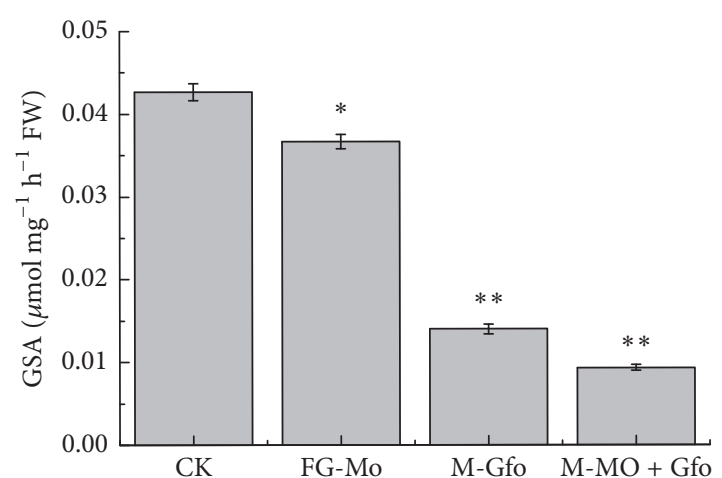

(b)

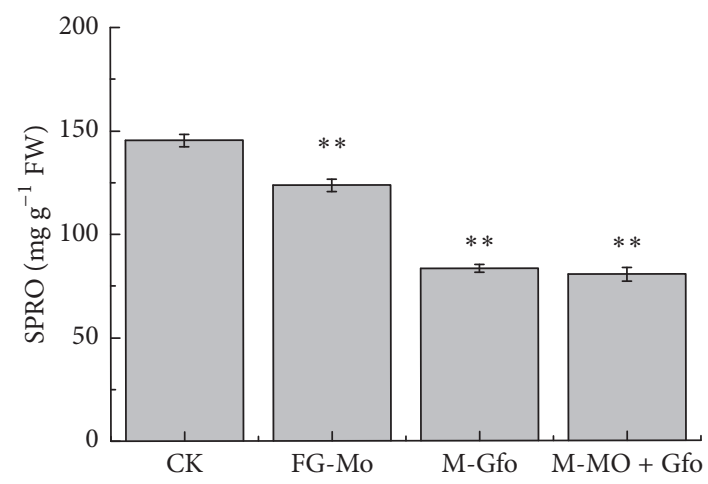

(d)

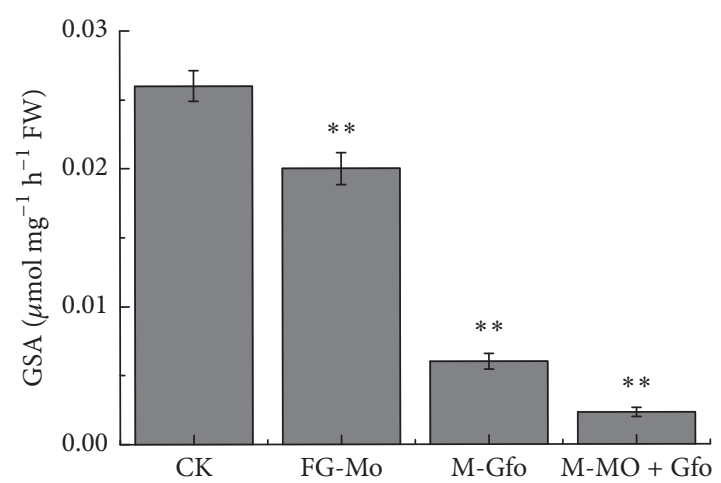

(f)

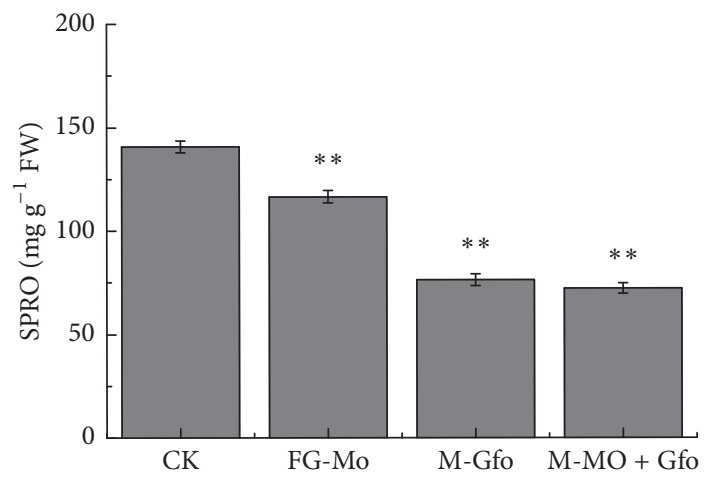

(h)

Figure 3: Effects of Mo and Gfo treatments on NRA, AVR, GSA, and SPRO in burley tobacco. Error bars represent standard error $(n=3)$. NRA: nitrate reductase activity; AVR: ammonia volatilization rate; GSA: glutamine synthetase activity; SPRO: total soluble protein content. (a-d) KT204. (e-h) TN86. Symbols $* *$ and $*$ indicate significant difference at 0.01 or 0.05 , respectively. 
TABLE 2: ANOVA comparison of the effects of regulatory treatments, year, and tobacco variety and their interactions on $\mathrm{TN}^{\mathrm{N}} \mathrm{NO}_{3}-\mathrm{N}, \mathrm{NO}_{2}-\mathrm{N}$, alkaloid, and TSNA concentrations in tobacco.

\begin{tabular}{|c|c|c|c|c|c|c|c|}
\hline Types & Effect & TN & $\mathrm{NO}_{3}-\mathrm{N}$ & $\mathrm{NO}_{2}-\mathrm{N}$ & Alkaloid & TSNAs & DF \\
\hline \multirow{3}{*}{ Flue-cured tobacco } & Year $(\mathrm{Y})$ & $0.05^{\mathrm{ns}}$ & $0.20^{*}$ & $0.01^{* *}$ & $1.60^{\mathrm{ns}}$ & $0.04^{* *}$ & 1 \\
\hline & Treatment $(\mathrm{T})$ & $9.01^{* *}$ & $15.33^{* *}$ & $0.21^{\mathrm{ns}}$ & $4.65^{*}$ & $7.19^{* *}$ & 3 \\
\hline & Year $(\mathrm{Y}) \times$ Treatment $(\mathrm{T})$ & $8.54^{* *}$ & $55.61^{* *}$ & $13.71^{* *}$ & $5.73^{* *}$ & $30.52^{* *}$ & 7 \\
\hline \multirow{3}{*}{ Burley tobacco } & Variety $(\mathrm{V})$ & $0.97^{*}$ & $0.18^{*}$ & $11.08^{* *}$ & $0.02^{* *}$ & $1.18^{*}$ & 1 \\
\hline & Treatment $(\mathrm{T})$ & $3.59^{*}$ & $19.34^{* *}$ & $0.97^{\mathrm{ns}}$ & $0.28^{\mathrm{ns}}$ & $18.68^{* *}$ & 3 \\
\hline & $\operatorname{Variety}(\mathrm{V}) \times$ Treatment $(\mathrm{T})$ & $5.66^{* *}$ & $275.57^{* *}$ & $28.41^{* *}$ & $13.14^{* *}$ & $274.77^{* *}$ & 7 \\
\hline
\end{tabular}

F-values and significance levels are given $\left({ }^{* *} p<0.01,{ }^{*} p<0.05\right.$, and $\left.{ }^{\mathrm{ns}} p \geq 0.05\right)$.

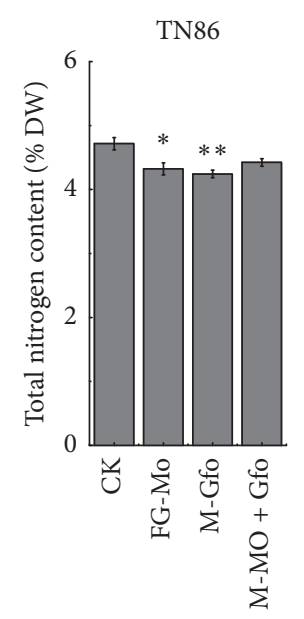

(a)

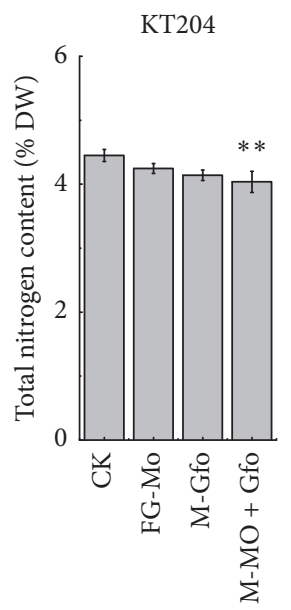

(f)

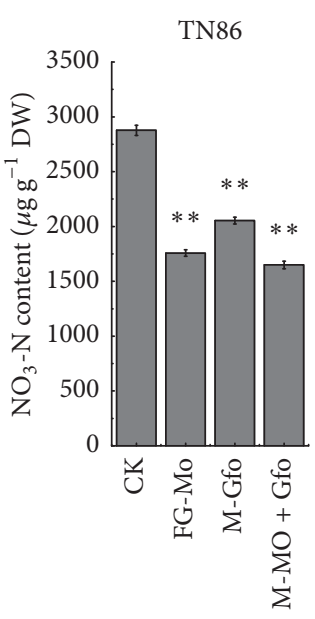

(b)

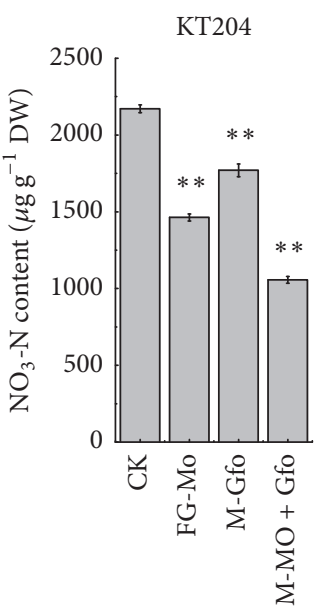

(g)

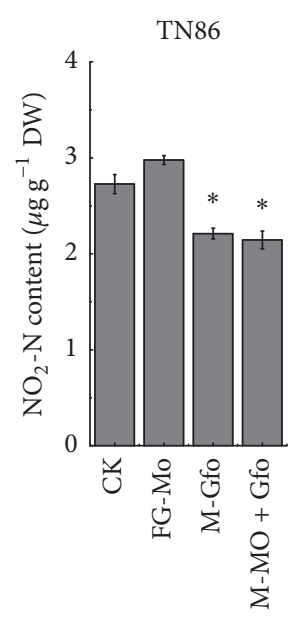

(c)

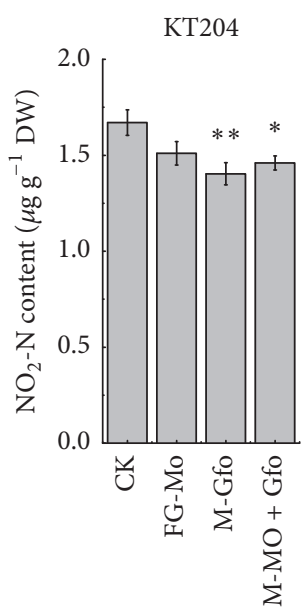

(h)

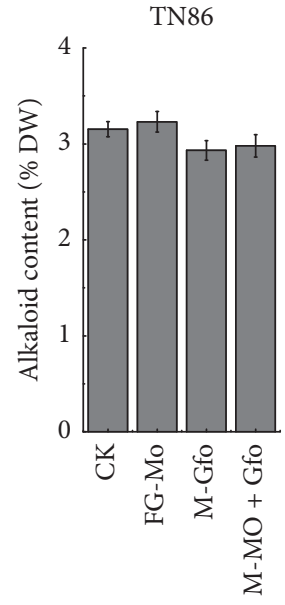

(d)

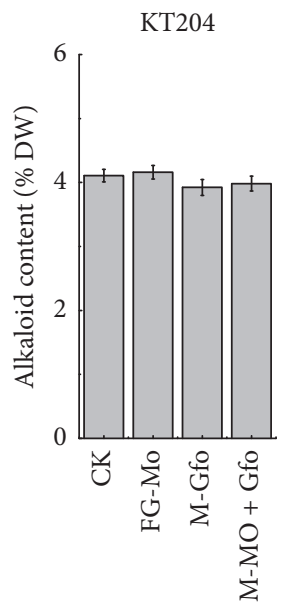

(i)

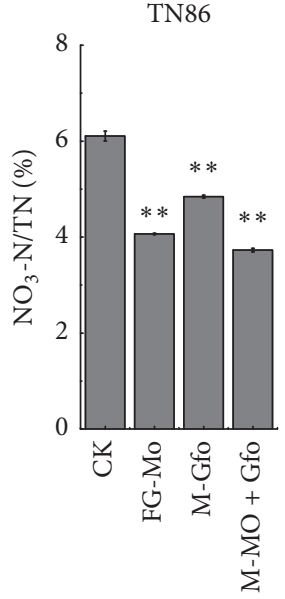

(e)

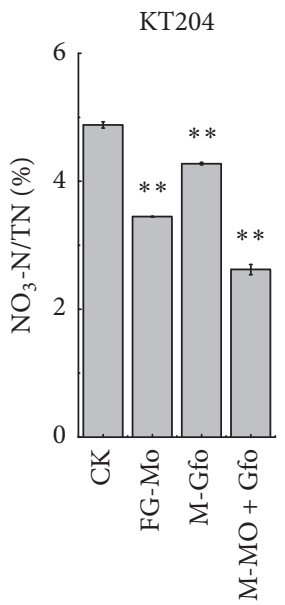

(j)

FiguRE 4: Effects of treatments on total nitrogen content, $\mathrm{NO}_{3}-\mathrm{N}$ content, $\mathrm{NO}_{2}-\mathrm{N}$ content, alkaloid content, and $\mathrm{NO}-\mathrm{N} / \mathrm{TN}$ in burley tobacco. $\mathrm{NO}_{3}-\mathrm{N} / \mathrm{TN}$ : ratio of $\mathrm{NO}_{3}-\mathrm{N}$ and total nitrogen content $(\mathrm{TN})$. Error bars represent standard error $(n=3)$. Symbols $* *$ and $*$ indicate significant difference at 0.01 or 0.05 , respectively.

the effect of spraying Mo during the fast-growth period was significantly different $(p<0.05)$. Spraying Mo during the fast-growth period and spraying Mo and Gfo at maturity produced the best results on TSNA concentrations among all treatments in both 2014 and 2015. Spraying Mo during the fast-growth period could significantly reduce concentrations of NNN, NAB, and NAT. Spraying Mo during the fast-growth period and spraying Gfo at the stage of maturity decreased NNN, NAB, NAT, and total TSNA concentration in both 2014 and 2015, respectively.

TSNA accumulation in burley tobacco was much higher than in flue-cured tobacco. However, effects of regulatory 


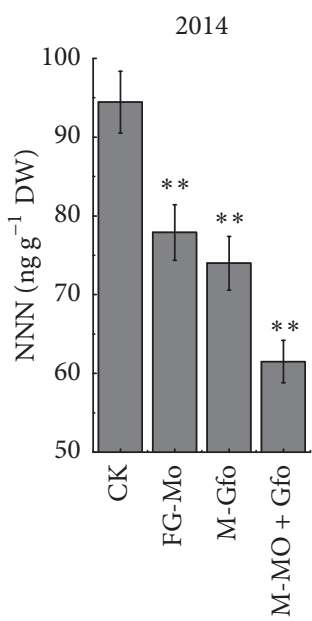

(a)

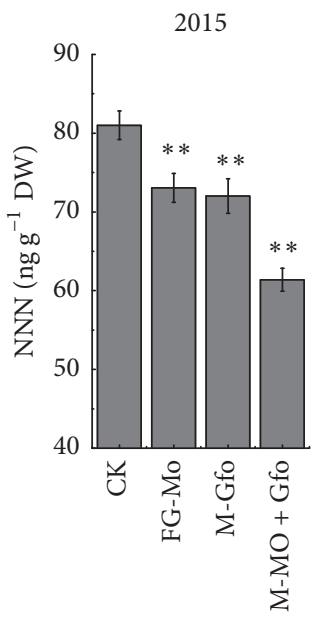

(f)

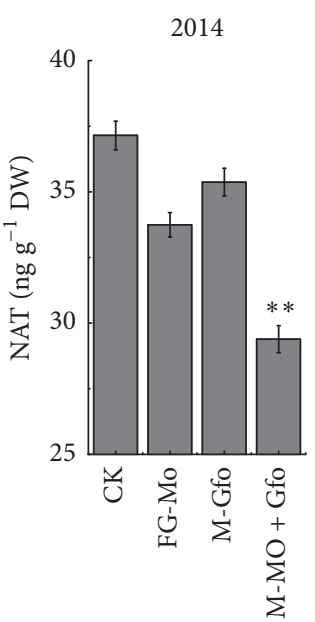

(b)

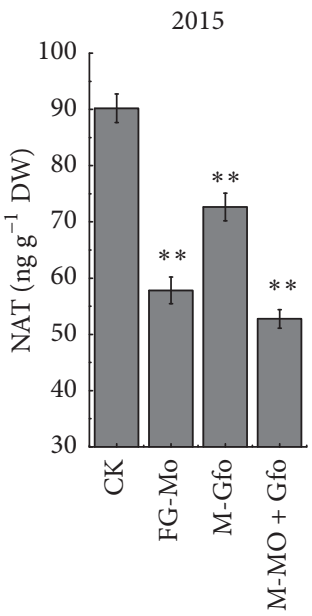

(g)

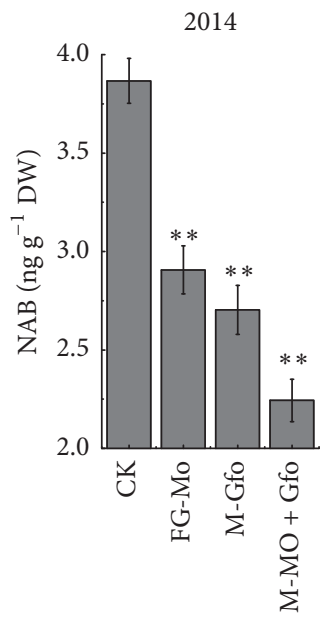

(c)

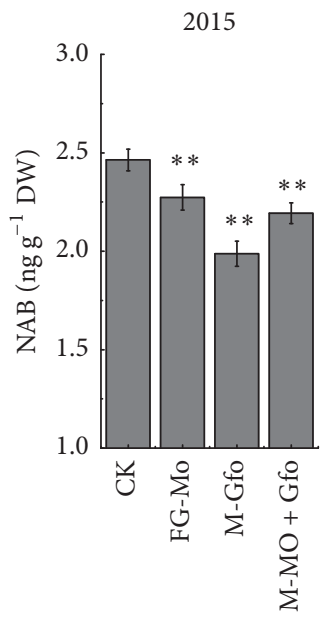

(h)

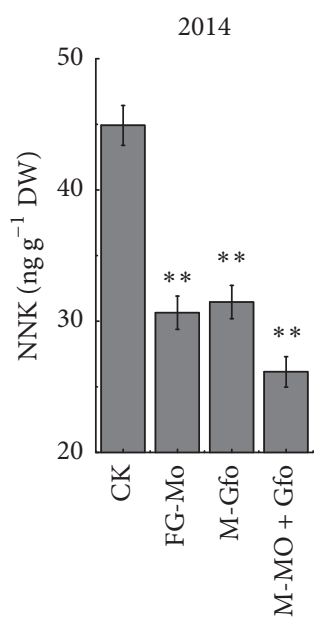

(d)

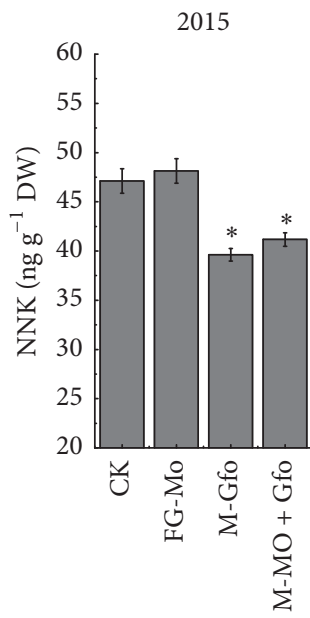

(i)

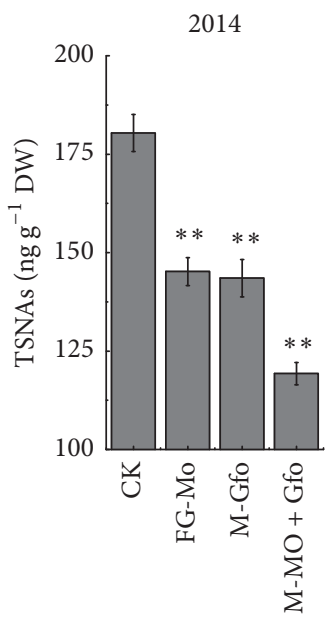

(e)

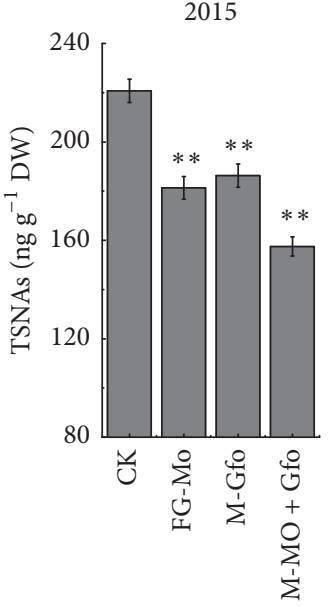

(j)

FIGURE 5: Effects of chemical regulation on NNN, NAB, NAT, NNK, and total TSNA concentration in flue-cured tobacco. Error bars indicate standard error $(n=3)$. Symbols $* *$ and $*$ indicate significant difference at 0.01 or 0.05 , respectively.

treatment were more pronounced in burley tobacco. Within burley varieties, the TSNA concentrations in KT204 were higher than that in TN86 (Figures 6(a)-6(e)). Spraying of Mo during the fast-growth period led to significantly lower $\mathrm{NNN}$, NAB, and total TSNA concentrations in KT204. Spraying of Gfo at maturity led to significant decreases in NNN, NAT, NNK, and TSNA concentrations in TN86. The TSNAregulating effects of the two treatments were optimized by spraying Mo during the fast-growth period and Gfo at the stage of maturity. NNN, NAT, NAB, NNK, and total TSNA concentration decreased in KT204 and TN86.

3.6. Correlation Analysis. Linear relationships between TSNAs, alkaloids, and $\mathrm{NO}_{3}-\mathrm{N}$ were significantly different (Figures $7(\mathrm{a})-7(\mathrm{c}))$. Total TSNA concentration in tobacco increased with increasing alkaloid and $\mathrm{NO}_{3}-\mathrm{N}$ content, especially in burley tobacco. The positive correlations between TSNAs and their precursors were also reported by Lewis et al. [57], who suggested that $\mathrm{NO}_{3}-\mathrm{N}$ was a stronger contributing factor to higher TSNA levels than increased alkaloid levels in burley tobacco.

\section{Conclusion}

Nitrate was higher in burley tobacco than in flue-cured tobacco, with both types showing peak nitrate content during the fast-growth period. Under Mo treatment at the stage of maturity to avoid nitrate accumulation, NRA, LDM, and DM in tobacco leaves increased. Spraying Mo in combination with Gfo at the stage of maturity led to increased NRA and lower GSA in tobacco, which could help decrease nitrate and nitrite content by increasing nitrogen loss via ammonia volatilization. In summary, spraying Mo during fast growth and spraying Mo with Gfo at the stage of maturity were effective in reducing the formation of TSNAs. 


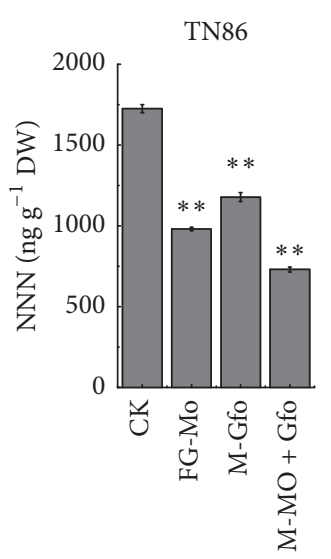

(a)

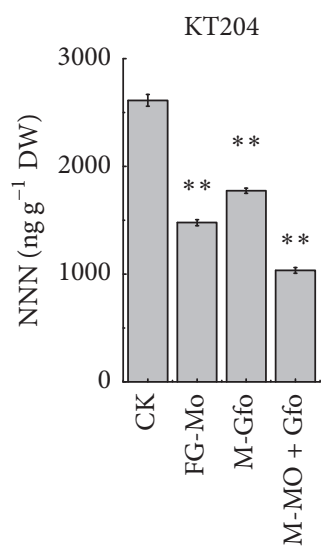

(f)

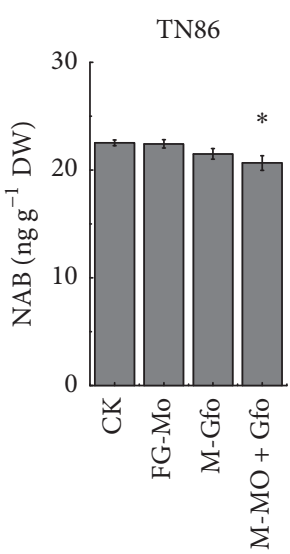

(b)

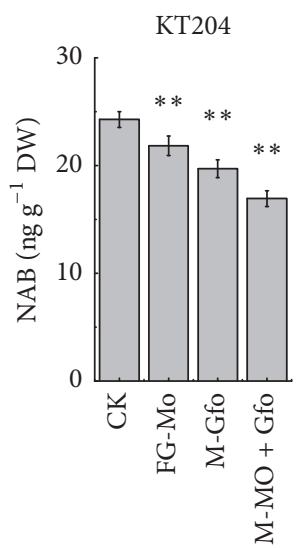

(g)

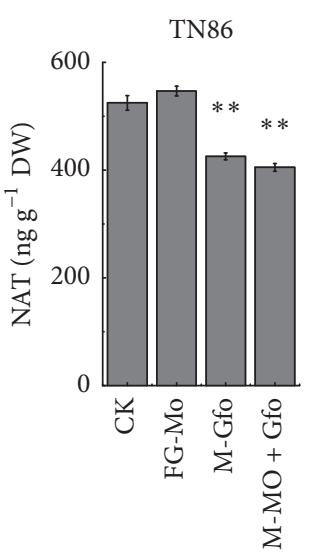

(c)

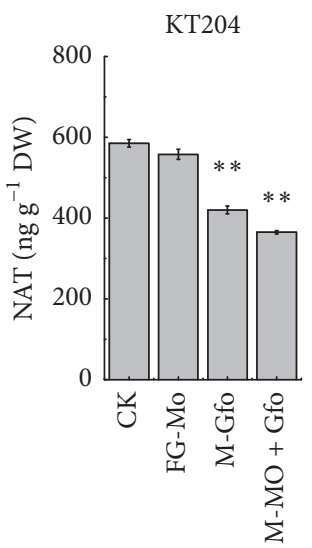

(h)

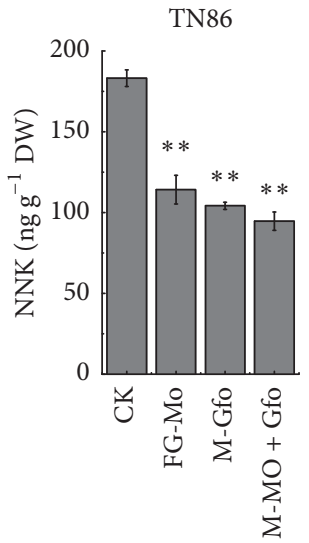

(d)

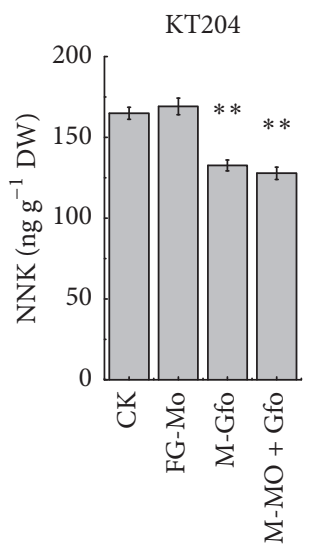

(i)

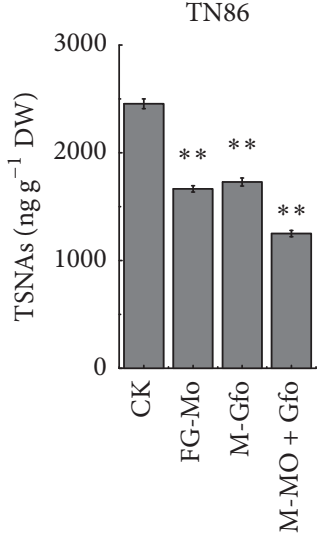

(e)

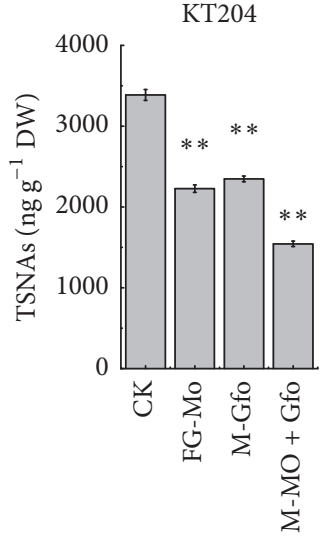

(j)

FIGURE 6: Effects of chemical regulation on NNN, NAB, NAT, NNK, and total TSNA concentration in burley tobacco varieties, TN86 and KT204. Error bars represent standard error $(n=3)$. Symbols $* *$ and $*$ indicate significant difference at 0.01 or 0.05 , respectively.

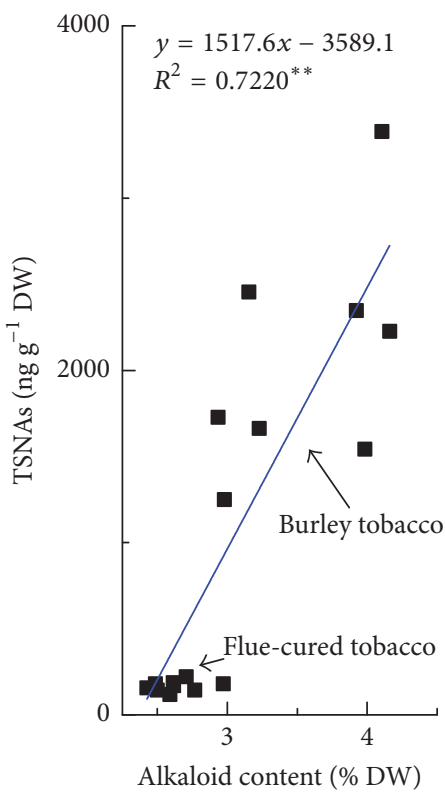

(a)

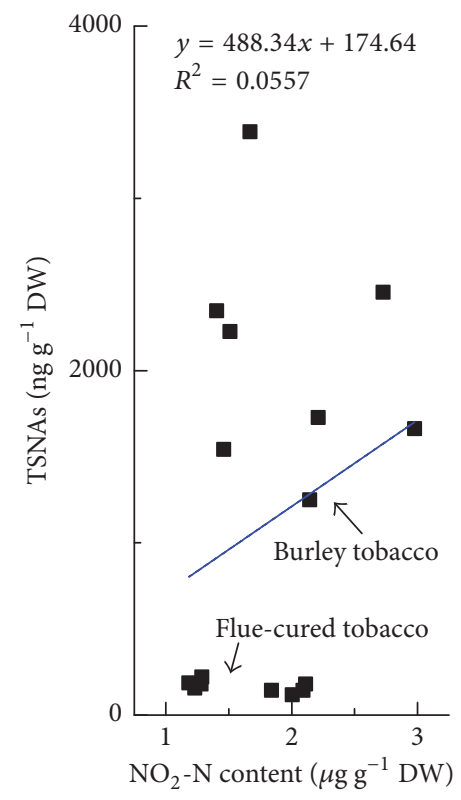

(b)

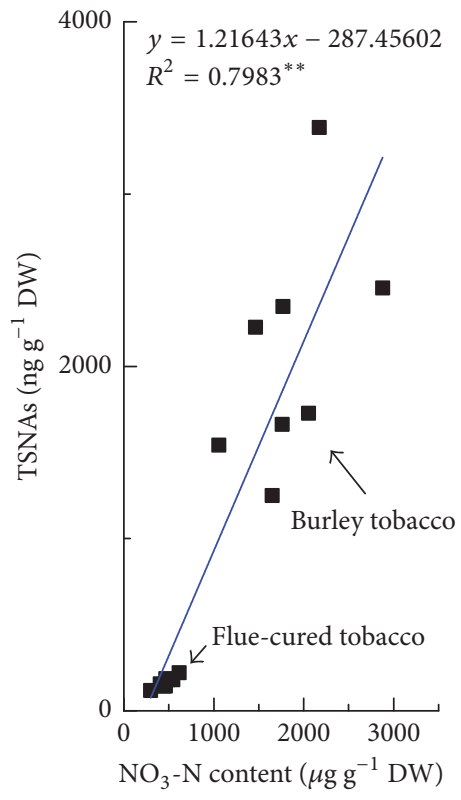

(c)

Figure 7: Correlation analysis between TSNAs, alkaloid, $\mathrm{NO}_{2}-\mathrm{N}$, and $\mathrm{NO}_{3}-\mathrm{N}$ in tobacco. Symbol $* *$ indicates significant correlation at $p<0.01$. 


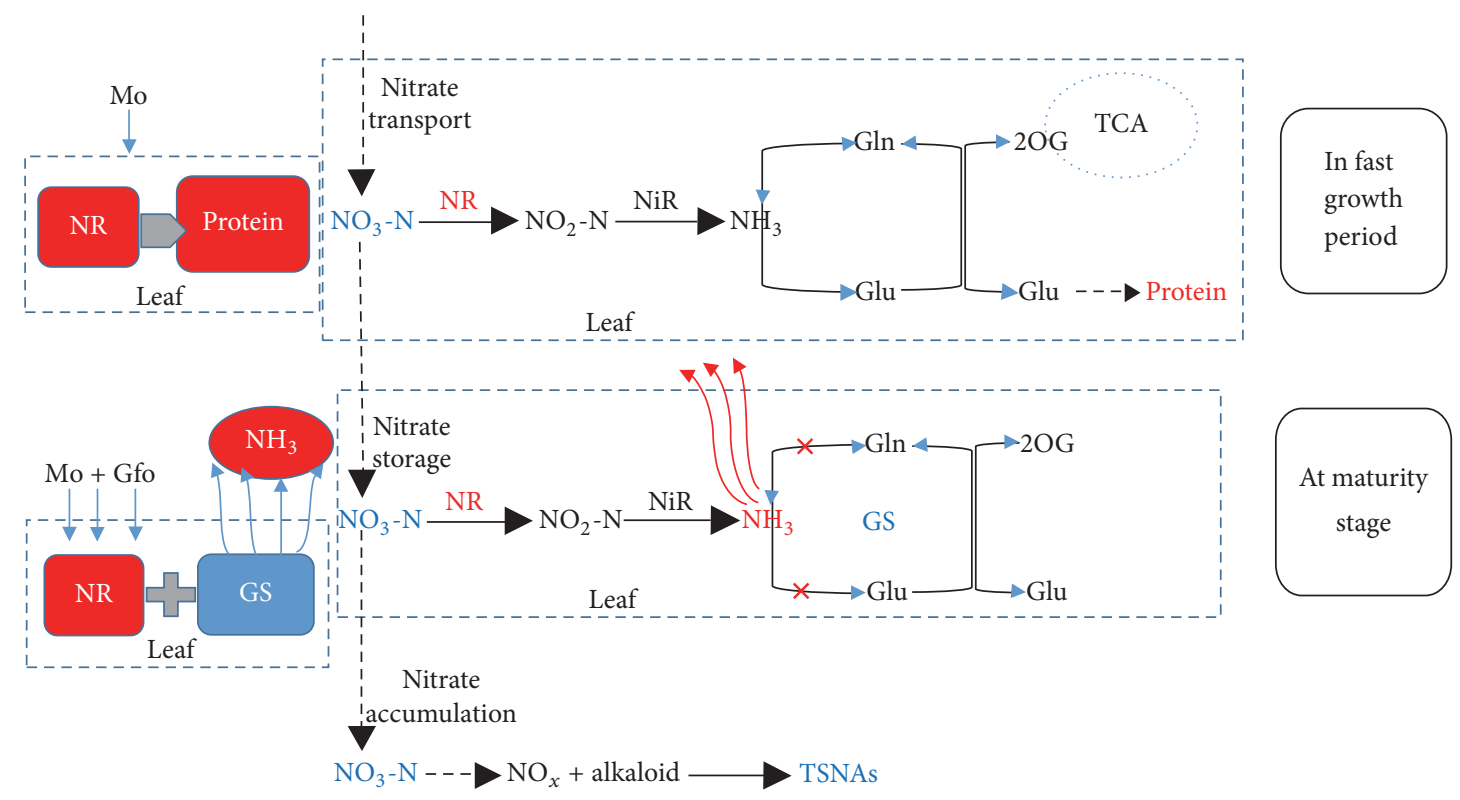

FIGURE 8: Mechanisms for decreasing nitrate and TSNA concentrations in tobacco by spraying regulating chemicals. Gfo: glufosinate, NR: nitrate reductase, NRA: nitrate reductase activity, NiR: nitrite reductase, GS: glutamine synthetase, GSA: glutamine synthetase activity, Gln: glutamine, Glu: glutamate, and OG: oxaloacetate. After spraying Mo on tobacco during the fast-growth period, nitrate significantly decreased while NRA and soluble protein content increased. These decreased the amount of nitrate storage and promoted tobacco development during the fast-growth period. After spraying Mo during the fast-growth stage and spraying Mo and Gfo at the stage of maturity, NRA increased and GSA decreased in tobacco, which can significantly reduce nitrate accumulation and TSNA formation by nitrogen loss due to ammonia volatilization.

\section{Conflicts of Interest}

The authors declare that there are no conflicts of interest regarding the publication of this paper.

\section{Acknowledgments}

The authors thank Editage (https://www.editage.com) for English language editing and publication support.

\section{References}

[1] H. R. Burton, N. K. Dye, and L. P. Bush, "Relationship between tobacco-specific nitrosamines and nitrite from different aircured tobacco varieties," Journal of Agricultural and Food Chemistry, vol. 42, no. 9, pp. 2007-2011, 1994.

[2] B. Siminszky, L. Gavilano, S. W. Bowen, and R. E. Dewey, "Conversion of nicotine to nornicotine in Nicotiana tabacum is mediated by CYP82E4, a cytochrome P450 monooxygenase," Proceedings of the National Acadamy of Sciences of the United States of America, vol. 102, no. 41, pp. 14919-14924, 2005.

[3] IARC, "Smokeless tobacco and some tobacco-specific Nnitrosamines, monographs on the evaluation of carcinogenic risks to humans," National Publishing Group, vol. 89, Article ID 1e592, 2005.

[4] H. Shi, R. Wang, and L. P. Bush, "The relationships between TSNAs and their precursors in burley tobacco from different regions and varieties, JournalofFood," AgricultureEnvironment, vol. 10, no. 2, pp. 1048-1052, 2012.
[5] H. R. Burton, G. H. Childs Jr., R. A. Andersen, and P. D. Fleming, "Changes in chemical composition of Burley tobacco during senescence and curing. 3. Tobacco-specific nitrosamines," Journal of Agricultural and Food Chemistry, vol. 37, no. 2, pp. 426-430, 1989.

[6] H. Shi, R. Wang, L. P. Bush et al., "Changes in TSNA Contents during Tobacco Storage and the Effect of Temperature and Nitrate Level on TSNA Formation," Journal of Agricultural and Food Chemistry, vol. 61, pp. 11588-11594, 2013.

[7] K. Fytianos and P. Zarogiannis, "Nitrate and nitrite accumulation in fresh vegetables from Greece," Bulletin of Environmental Contamination and Toxicology, vol. 62, no. 2, pp. 187-192, 1999.

[8] Y. Y. Wang, P. K. Hsu, and Y. F. Tsay, "Uptake, allocation and signaling of nitrate," Trends in Plant Science, vol. 17, no. 8, pp. 458-467, 2012.

[9] K. S. Reddy and R. C. Menary, "Nitrate reductase and nitrate accumulation in relation to nitrate toxicity in Boronia megastigma," Physiologia Plantarum, vol. 78, no. 3, pp. 430-434, 1990.

[10] Y. Han, Q. Liao, Y. Yu et al., "Nitrate reutilization mechanisms in the tonoplast of two Brassica napus genotypes with different nitrogen use efficiency," Acta Physiologiae Plantarum, vol. 37, no. 2, 2015.

[11] H. Kosaka, K. Imaizumi, K. Imai, and I. Tyuma, "Stoichiometry of the reaction of oxyhemoglobin with nitrite," BBA - Protein Structure, vol. 581, no. 1, pp. 184-188, 1979.

[12] P. Santamaria, "Nitrate in vegetables: toxicity, content, intake and EC regulation," Journal of the Science of Food and Agriculture, vol. 86, no. 1, pp. 10-17, 2006.

[13] A. T. Diplock, P. J. Aggett, M. Ashwell, F. Bornet, E. B. Fern, and M. B. Roberfroid, "Scientific concepts of functional foods in 
europe: consensus document," British Journal of Nutrition, vol. 81, supplement 1, pp. 1-28, 1999.

[14] C. M. Onyango, J. Harbinson, J. K. Imungi, S. S. Shibairo, and O. van Kooten, "Influence of organic and mineral fertilization on germination, leaf nitrogen, nitrate accumulation and yield of vegetable amaranth," Journal of Plant Nutrition, vol. 35, no. 3, pp. 342-365, 2012.

[15] I. S. Vieira, E. P. Vasconcelos, and A. A. Monteiro, "Nitrate accumulation, yield and leaf quality of turnip greens in response to nitrogen fertilisation," Nutrient Cycling in Agroecosystems, vol. 51, no. 3, pp. 249-258, 1998.

[16] K. Reinink and A. H. Eenink, "Genotypical differences in nitrate accumulation in shoots and roots of lettuce," Scientia Horticulturae, vol. 37, no. 1-2, pp. 13-24, 1988.

[17] I. G. Burns, K. Zhang, M. K. Turner et al., "Screening for genotype and environment effects on nitrate accumulation in 24 species of young lettuce," Journal of the Science of Food and Agriculture, vol. 91, no. 3, pp. 553-562, 2011.

[18] F. C. Olday, A. V. Barker, and D. N. Maynard, "A physiological basis for different patterns of nitrate accumulation in two spinach cultivars," JournaloftheAmericanSocietyofHorticulturalScientists, vol. 101, pp. 217-219, 1976.

[19] Y. Tang, X. Sun, C. Hu, Q. Tan, and X. Zhao, “Genotypic differences in nitrate uptake, translocation and assimilation of two Chinese cabbage cultivars [Brassica campestris L. ssp. Chinensis(L.)]," Plant Physiology and Biochemistry, vol. 70, pp. 14-20, 2013.

[20] R. R. Mendel and F. Bittner, "Cell biology of molybdenum," Biochimica et Biophysica Acta (BBA) - Molecular Cell Research, vol. 1763, no. 7, pp. 621-635, 2006.

[21] M. Farooq, A. Wahid, and K. H. M. Siddique, "Micronutrient application through seed treatmentsa review," Journal of Soil Science and Plant Nutrition, vol. 12, no. 1, pp. 125-142, 2012.

[22] C. M. J. Williams, N. A. Maier, and L. Bartlett, "Effect of molybdenum foliar sprays on yield, berry size, seed formation, and petiolar nutrient composition of "Merlot" grapevines," Journal of Plant Nutrition, vol. 27, no. 11, pp. 1891-1916, 2004.

[23] G. A. Biscaro, S. A. R. Goulart Jr, and R. P. Soratto, "Molybdenum applied to seeds and side dressing nitrogen on irrigated

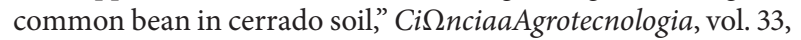
pp. 1280-1287, 2009.

[24] K. Ramesh and V. Thirumurugan, "Effect of seed pelleting and foliar nutrition on growth of soybean," Madras Agricultural Journal, vol. 88, pp. 465-468, 2001.

[25] R. D. Blackwell, A. J. S. Murray, and P. J. Lea, "Inhibition of photosynthesis in barley with decreased levels of chloroplastic glutamine synthetase activity," Journal of Experimental Botany, vol. 38, no. 11, pp. 1799-1809, 1987.

[26] A. Wild, H. Sauer, and W. Rühle, "The effect of phosphinothricin (glufosinate) on photosynthesis I. Inhibition of photosynthesis and accumulation of ammonia," Zeitschrift fur Naturforschung - Section C Journal of Biosciences, vol. 42, no. 3, pp. 263-269, 1987.

[27] H. Sauer, A. Wild, and W. Rühle, "The effect of phosphinothricin (glufosinate) on photosynthesis ii. the causes of inhibition of photosynthesis," Zeitschrift fur Naturforschung Section C Journal of Biosciences, vol. 42, no. 3, pp. 270-278, 1987.

[28] A. Wild and C. Wendler, "Effect of glufosinate (phosphinothricin) on amino acid content, photorespiration and photosynthesis," PesticideScience, vol. 30, pp. 422-424, 1991.
[29] C. Wendler, M. Barniske, and A. Wild, "Effect of phosphinothricin (glufosinate) on photosynthesis and photorespiration of $\mathrm{C}_{3}$ and $\mathrm{C}_{4}$ plants," Photosynthesis Research, vol. 24, no. 1, pp. 55-61, 1990.

[30] J. F. Seelye, W. M. Borst, G. A. King, P. J. Hannan, and D. Maddocks, "Glutamine synthetase activity, ammonium accumulation and growth of callus cultures of Asparagus officinalis L. exposed to high ammonium or phosphinothricin," Journal of Plant Physiology, vol. 146, no. 5-6, pp. 686-692, 1995.

[31] R. Manderscheid, S. Schaaf, M. Mattsson, and J. K. Schjoerring, "Glufosinate treatment of weeds results in ammonia emission by plants," Agriculture, Ecosystems \& Environment, vol. 109, no. 1-2, pp. 129-140, 2005.

[32] Q. Zhang, Q. Song, C. Wang, C. Zhou, C. Lu, and M. Zhao, "Effects of glufosinate on the growth of and microcystin production by Microcystis aeruginosa at environmentally relevant concentrations," Science of the Total Environment, vol. 575, pp. 513-518, 2017.

[33] D. Xu, J. Sun, and H. Yang, "Inhibitory effects of enzymes on nitrogen metabolism at mature stage and quality of cured tobacco leaves," Journalof TobaccoScienceTechnology, vol. 49, no. 3, pp. 17-23, 2016.

[34] H. Zhang, X. Liu, and J. Zhang, "Mechanism and utilization of glufosinate-ammonium," PesticideScienceandAdministration, vol. 25, no. 4, pp. 23-27, 2005.

[35] B. A. Sellers, R. J. Smeda, and J. Li, "Glutamine synthetase activity and ammonium accumulation is influenced by time of glufosinate application," Pesticide Biochemistry and Physiology, vol. 78, no. 1, pp. 9-20, 2004.

[36] N. K. Moustakas and H. Ntzanis, "Dry matter accumulation and nutrient uptake in flue-cured tobacco (Nicotiana tabacum L.)," Field Crops Research, vol. 94, no. 1, pp. 1-13, 2005.

[37] National Tobacco Institute of Greece, Guidelines for Tobacco Production, 1996.

[38] S. D. Bao, Agricultural and Chemistry Analysis of Soil, Agriculture Press, Beijing (in Chinese, 2005.

[39] H. S. Li, Principle and technology of plant physiological and biochemical experiments, Higher Education Press, Beijing, 2000.

[40] D. O'Neal and K. W. Joy, "Glutamine synthetase of pea leaves," Journal of Plant Physiology, vol. 54, no. 5, pp. 773-779, 1974.

[41] F. J. Dentener and P. J. Crutzen, "A three-dimensional model of the global ammonia cycle," Journal of Atmospheric Chemistry, vol. 19, no. 4, pp. 331-369, 1994.

[42] J. D. Crutchfield and J. H. Grove, "A new cadmium reduction device for the microplate determination of nitrate in water, soil, plant tissue, and physiological fluids," Journal of AOAC International, vol. 94, no. 6, pp. 1896-1905, 2011.

[43] A. Jack and L. Bush, "The "LC" protocol - Appendix 3: Laboratory Procedures," pp. 21-23. University of Kentucky, Lexington, USA (2007)," http://www.uky.edu/Ag/Tobacco/Pdf/ 327LC-Protocol.

[44] X. Wei, X. Deng, D. Cai et al., "Decreased tobacco-specific nitrosamines by microbial treatment with Bacillus amyloliquefaciens DA9 during the air-curing process of burley tobacco," Journal of Agricultural and Food Chemistry, vol. 62, no. 52, pp. 12701-12706, 2014.

[45] W. Morgan, J. Reece, C. Risner et al., "A collaborative study for the determination of tobacco specific nitrosamines in tobacco," Beiträge zur Tabakforschung International, vol. 21, no. 3, pp. 192203, 2014. 
[46] J. Zhou, R. Bai, and Y. Zhu, "Determination of four tobaccospecific nitrosamines in mainstream cigarette smoke by gas chromatography/ion trap mass spectrometry," Rapid Communications in Mass Spectrometry, vol. 21, no. 24, pp. 4086-4092, 2007.

[47] SY. Ai, J. W. Yao, and X. H. Huang, "Study on the nitrate reduction characteristic of vegetables," Plant Nutrition and Fertilizer Science, vol. 8, no. 1, pp. 40-43, 2002.

[48] Y. Li, D. Chang, J. Sun, H. Yang, J. Wang, and H. Shi, "Difference of nitrogen metabolism between flue-cured tobacco and burley tobacco seedlings," Tobacco Science \& Technology, vol. 50, no. 1, pp. 6-11, 2017.

[49] Z. Q. Shang, "Effects of nitrogen amount on growth and development yield and quality in burley tobacco," Chinese Agricultural Science Bulletin, vol. 23, pp. 299-301, 2007.

[50] Z. H. Li, Z. Song, and G. Huang, "Effects of molybdenum applying in tobacco field on photosynthesis, nitrogen metabolism and quality of tobacco," Tobacco Science \& Technology, vol. 11, pp. 56-58, 2008.

[51] N. Nautiyal and C. Chatterjee, "Molybdenum Stress-Induced Changes in Growth and Yield of Chickpea," Journal of Plant Nutrition, vol. 27, no. 1, pp. 173-181, 2004.

[52] N. C. Gopalachari, A. Sastry, and D. Rao, "Effect of maturity of leaf at harvest on some physical and chemical properties of cured leaf of, Delcrest, flue-cured tobacco Nicotianatabacum L," IndianJournalofAgriculturalScience, vol. 10, pp. 901-911, 1970.

[53] Z. Zhang, S. Xiong, Y. Wei, X. Meng, X. Wang, and X. Ma, “The role of glutamine synthetase isozymes in enhancing nitrogen use efficiency of N-efficient winter wheat," Scientific Reports, vol. 7, no. 1, 2017.

[54] J. Wang, H. Yang, H. Shi et al., "Nitrate and Nitrite Promote Formation of Tobacco-Specific Nitrosamines via Nitrogen Oxides Intermediates during Postcured Storage under Warm Temperature," Journal of Chemistry, vol. 2017, pp. 1-11, 2017.

[55] S. Liang, Study on mechanism of exogenous substances reducing TSNA content in burley tobacco [Master, thesis], Masters Dissertation., Wuhan, Huazhong Agriculture University, 2013.

[56] H. Liu, J. Han, and S. Yang, "Effect of malonate acid on nicotine in burley tobacco," ActaTobacariaSinica, vol. 6, no. 3, pp. 47-48, 2000.

[57] R. S. Lewis, R. G. Parker, D. A. Danehower et al., "Impact of alleles at the Yellow Burley (Yb) loci and nitrogen fertilization rate on nitrogen utilization efficiency and tobacco-specific nitrosamine (TSNA) formation in air-cured tobacco," Journal of Agricultural and Food Chemistry, vol. 60, no. 25, pp. 6454-6461, 2012. 

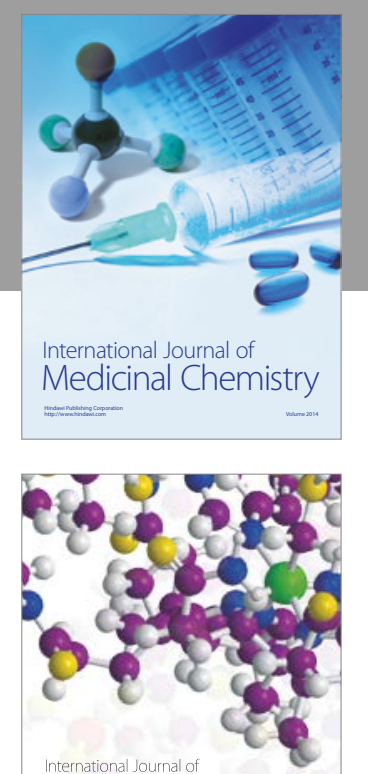

Carbohydrate Chemistry

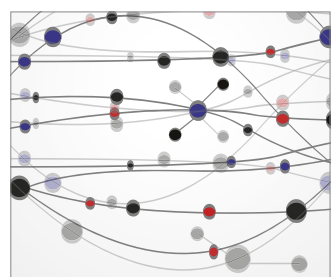

The Scientific World Journal
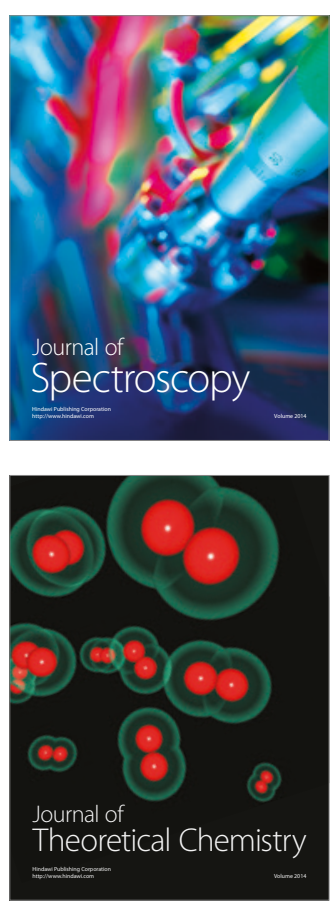
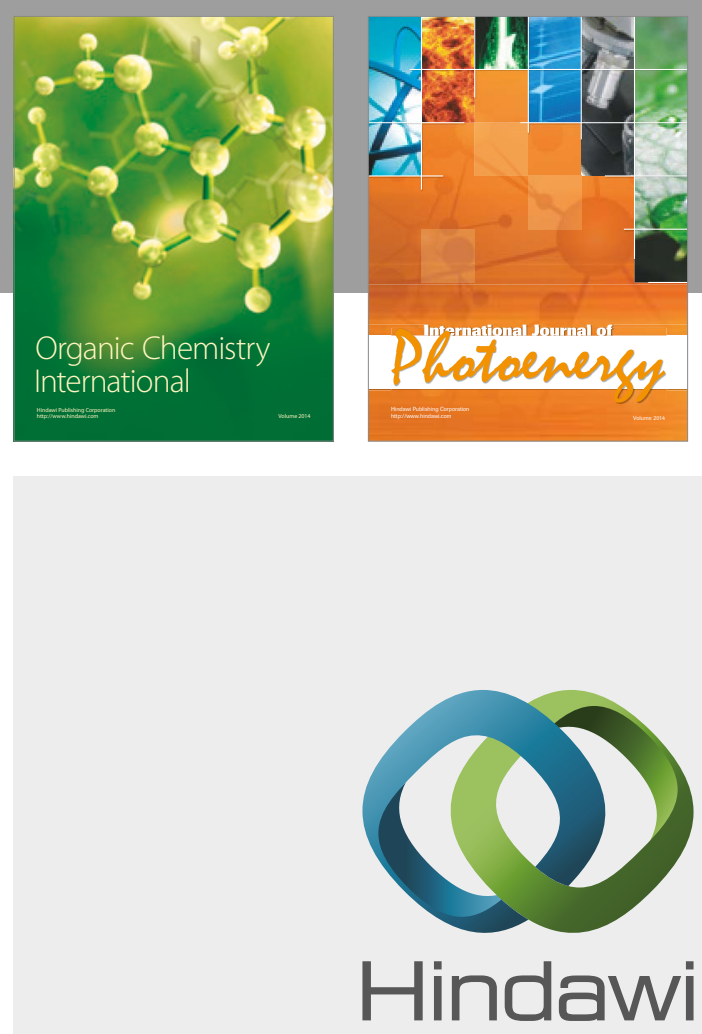

Submit your manuscripts at

https://www.hindawi.com

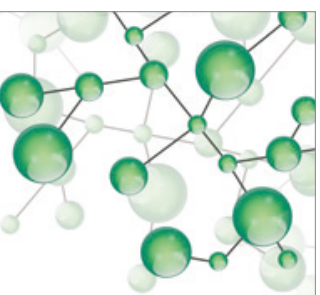

International Journal of

Inorganic Chemistry

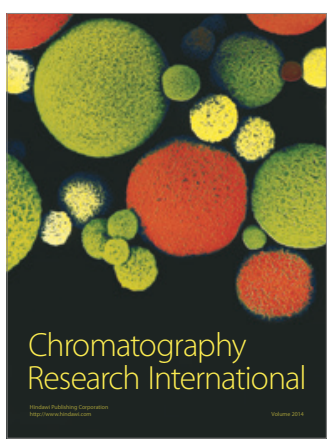

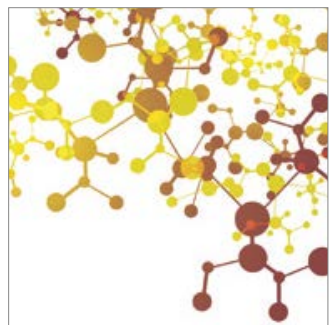

Applied Chemistry
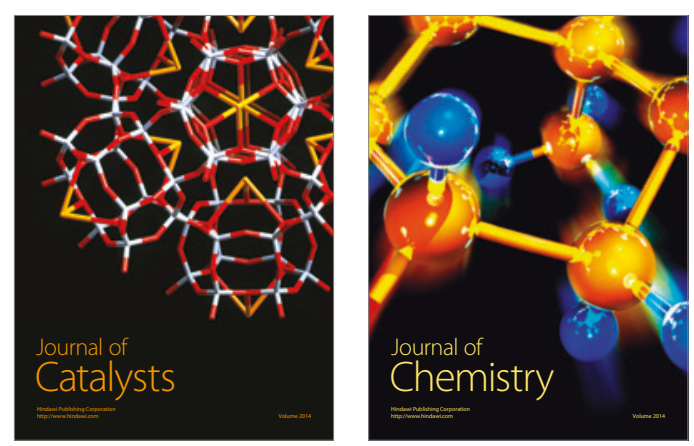
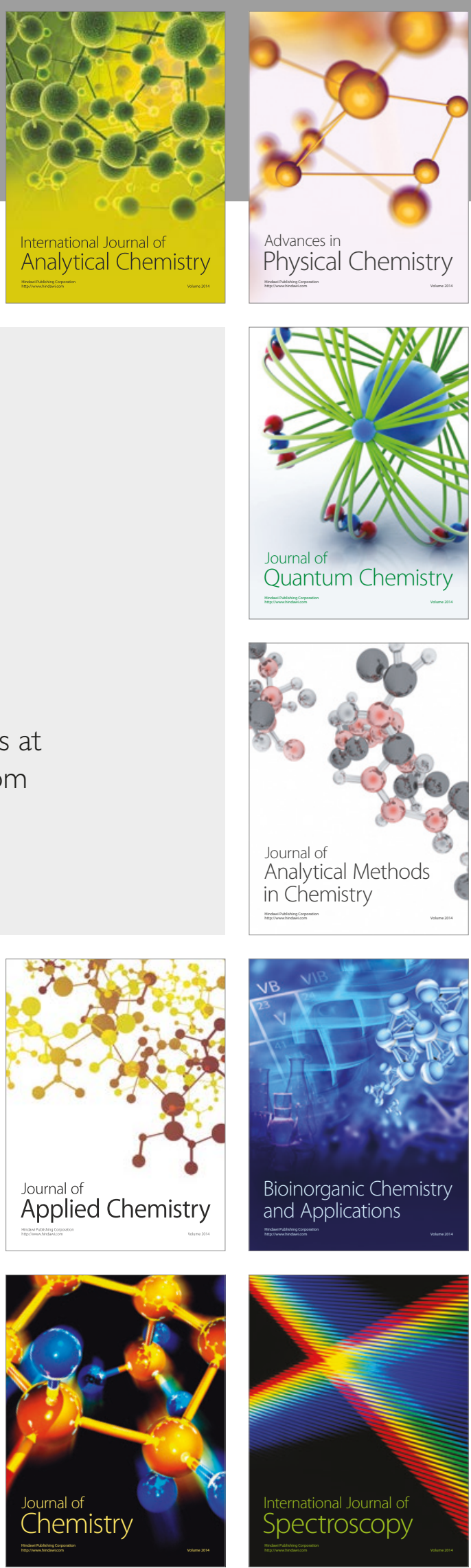